Article

\title{
Sulfides Formation in Carbothermic Reduction of Saprolitic Nickel Laterite Ore Using Low-Rank Coals and Additives: A Thermodynamic Simulation Analysis
}

\author{
Sri Harjanto ${ }^{1, *(\mathbb{D})}$ and M. Akbar Rhamdhani ${ }^{2}$ (C) \\ 1 Department of Metallurgical and Materials Engineering, Faculty of Engineering, University of Indonesia, \\ Kampus Baru UI, Depok 16424, Indonesia \\ 2 Department of Mechanical and Product Design Engineering, Swinburne University of Technology, \\ Melbourne, VIC 3122, Australia; arhamdhani@swin.edu.au \\ * Correspondence: sri.harjanto@ui.ac.id; Tel.: +62-217-863-510
}

Received: 9 September 2019; Accepted: 14 October 2019; Published: 15 October 2019

\begin{abstract}
In this paper, a systematic thermodynamic analysis of carbothermic reduction of saprolitic nickel laterite ore was carried out. Different carbon sources-such as pure C, sub-bituminous, and lignite-were used for the carbothermic reduction at $1000{ }^{\circ} \mathrm{C}(1273 \mathrm{~K})$. The effect of the different additives-such as $\mathrm{S}, \mathrm{FeS}, \mathrm{Na}_{2} \mathrm{~S}, \mathrm{Na}_{2} \mathrm{SO}_{4}$, and $\mathrm{CaSO}_{4}$ - was also systematically evaluated. The thermodynamic calculations suggested that the use of low rank coals (sub-bituminous and lignite) do not significantly affect the nickel grade and nickel recovery, but affect the total metals recovery. The presence of $S$ in these $C$-sources promoted the formation of sulfides. At $1000{ }^{\circ} \mathrm{C}(1273 \mathrm{~K})$, only a small amount of $\mathrm{C}$-sources ( $\mathrm{C}$, sub-bituminous, lignite) are needed to significantly metallize the nickel in the laterite, i.e., between 4-6 wt \%. The additives $\mathrm{S}, \mathrm{FeS}, \mathrm{Na}_{2} \mathrm{~S}, \mathrm{Na}_{2} \mathrm{SO}_{4}$, and $\mathrm{CaSO}_{4}$ were predicted to promote the formation of liquid sulfides, and at the same time reduce the formation of the $(\mathrm{Fe}, \mathrm{Ni})$ alloy, thus reducing the nickel and total metals recovery. Therefore, consideration is needed to balance the two aspects. The calculations predicted that $\mathrm{S}, \mathrm{Na}_{2} \mathrm{SO}_{4}$, and $\mathrm{CaSO}_{4}$ additions provided an increase in the nickel grade; while $\mathrm{FeS}$ and $\mathrm{Na}_{2} \mathrm{~S}$ reduced the nickel grade.
\end{abstract}

Keywords: carbothermic reduction; saprolitic nickeliferous; lignite; sub-bituminous; $\mathrm{S}$ addition; FeS addition; $\mathrm{Na}_{2} \mathrm{~S}$ addition; $\mathrm{Na}_{2} \mathrm{SO}_{4}$ addition; $\mathrm{CaSO}_{4}$ addition

\section{Introduction}

The latest data on world nickel reserves shows that the amount of nickel ore with grade of $1 \%$ or greater is still present with the amount of at least 130 million tons of nickel [1]. The reserve contains about $60 \%$ in laterite and $40 \%$ in sulfide deposits. In tropical areas-such as Indonesia, some parts of Australia, and the rest of the world-laterite nickel reserves are widely explored and become the main reserves of nickel metal extraction, with a small portion containing cobalt and other metals. Even since the last decade, the use of nickel mineral ore of lower grade has been increasing due to reduced reserves of high-grade nickel [2]. In general, nickeliferous laterite ore comprises of saprolitic ore (silicate/hydrosilicate type) and limonitic ore (oxide/hydroxide type) [3]. Nickeliferous laterite ore has complex composition and mineralogy; and it contains different metals such as iron, magnesium, aluminum, silicon, nickel, cobalt, manganese, and others. Comprehensive microstructure characterizations carried out previously by Rhamdhani et al. [4] show that typical lateritic ore contain composite and single-phase particles of different sizes having structure of composite mixture, fine grain mixture, intergrowth, vein-like/plate-like, porous, and dense, depending on the degree of weathering. This complex microstructure and the broad spectrum of chemical alteration due to weathering effect results in the difficulties in the beneficiation process of the ore. 
The pyrometallurgical route offers processes for extracting nickel from the nickeliferous laterite ore by selective chemical reaction at high temperatures, for example through carbothermic reduction [5]. Different carbonaceous reductants, such as low-rank coals (sub-bituminous and lignite/brown coal), can potentially be used for this purpose. Sub-bituminous is a low-grade coal which contains less carbon and high levels of sulfur. Categorized based on the grade of different coals, there are approximately $32 \%$ sub-bituminous and 18\% lignite coals reserves in the world, respectively [6]. In 2013, sub-bituminous and lignite reserves in Indonesia were estimated to be around 28,017 million tons; while reserves around the world were around 488,332 million tonnes [7]. Considering the large reserves of both nickel laterites and low-rank coals in Indonesia and around the world, it is important to develop a fundamental understanding for the development of appropriate processing routes for utilizing these resources.

There have been many of studies on laterite processing, in particular on looking at the effect of key parameters such as temperature, reduction conditions and phase transformations [8,9]. Rao et al. [10] provided a thorough review on carbothermic reduction of laterite ores with focus on the production of nickel pig iron in China. They pointed out that low-temperature reduction of laterite ores followed by physical separation (e.g., magnetic separation) to liberate ferronickel alloy could be an alternative way to recover the valuable metals from the low-grade ores. A number of studies had been carried out to investigate different additives (particularly that contain S) that can promote the growth and coalescence of $\mathrm{Fe}, \mathrm{Ni}$ alloy during the low temperature reduction of laterite ore.

Rhamdhani et al. [4,11] carried out detailed laterite (mixture of limonitic and saprolitic) characterization, and thermodynamic and phase transformation at conditions relevant to an industrial Caron process, i.e., $\mathrm{T}=650-800^{\circ} \mathrm{C}(\mathrm{T}=923-1073 \mathrm{~K}) ; \mathrm{pO}_{2}=10^{-16}$ to $10^{-21} \mathrm{~atm}$. They pointed out that, at these conditions, the extraction of $\mathrm{Ni}$ from limonitic is limited by thermodynamics, while the condition for a saprolitic ore depends on the composition of the olivine $(\mathrm{Mg} / \mathrm{Fe}$ ratio). They reported that nickel recovery is better when the $\mathrm{Mg} / \mathrm{Fe}$ ratio is less than 8 . Pickles et al. [12] carried out thermodynamic analysis of carbothermic reduction of limonitic laterite ore. They only considered limited species associated with $\mathrm{Fe}, \mathrm{Ni}, \mathrm{Co}, \mathrm{Mg}, \mathrm{Si}, \mathrm{O}$, and $\mathrm{H}$ in the modeling. Their thermodynamic results suggested that formations $\mathrm{Fe}$ and $\mathrm{Ni}$ are coincide with each other. They reported nickel recoveries of $90-93 \%$ for reactions with $3.6 \mathrm{wt} \% \mathrm{C}$ at $540-740{ }^{\circ} \mathrm{C}(813-1013 \mathrm{~K})$. A decrease in nickel recovery above $625{ }^{\circ} \mathrm{C}(898$ $\mathrm{K})$ was reported and was attributed to the formation of $(\mathrm{Ni}, \mathrm{Fe}) \mathrm{O}$. They also reported that the nickel grade is decreasing with increasing metal recovery.

Elliott et al. $[13,14]$ extended the study and investigated the effect of addition of sulfur on the limonitic ore reduction. Their thermodynamic calculation showed that nickel recovery increases with increasing carbon and sulfur addition; and this was in agreement with their experimental study. They reported that at least $4 \mathrm{wt} \% \mathrm{~S}$ is needed for assisting ( $\mathrm{Fe}, \mathrm{Ni}$ ) alloy particle growth (as the majority of $\mathrm{S}$ was lost during heating and that only about $10 \mathrm{wt} \%$ residual S remaining at $1000{ }^{\circ} \mathrm{C}(1273 \mathrm{~K})$. Typical alloy particle size of 10-20 $\mu \mathrm{m}$ was reported, and a maximum particle size of $120 \mu \mathrm{m}$ was observed for reduction carried out at $1200{ }^{\circ} \mathrm{C}(1473 \mathrm{~K})$ for $60 \mathrm{~min}$. In another study, Elliott et al. [14] investigated the addition of $\mathrm{S}(0-4 \mathrm{wt} \%)$ and pyrite $(0-11.25 \mathrm{wt} \%)$ on carbothermic reduction of limonite using coal $(0-6 \mathrm{wt} \%)$ at $1000-1200{ }^{\circ} \mathrm{C}(1273-1473 \mathrm{~K})$. They reported that the alloy particles grow through liquid phase sintering mechanism, promoted by liquid phase at the interface between the alloy and the sulfide. Pyrite additions was reported to provide higher residual sulfur available to react at targeted temperatures, thus produced larger ferronickel alloy particles.

Forster et al. [15] carried out a thermodynamic modeling of carbothermic reduction of saprolitic laterite ore and an experimental study using microwave heating for the process. From their thermodynamic calculations, they suggested that formation of nickel occurs at about $790{ }^{\circ} \mathrm{C}(1063 \mathrm{~K})$ for carbon additions in the range of 2.25-6 wt \%. They also suggested that $5 \mathrm{wt} \% \mathrm{C}$ addition at $880{ }^{\circ} \mathrm{C}$ $(1153 \mathrm{~K})$ result in a nickel grade of $8.5 \%$ and nickel recovery of $98 \%$. At $1000{ }^{\circ} \mathrm{C}(1273 \mathrm{~K}), 4 \mathrm{wt} \% \mathrm{C}$ was reported to provide nickel recovery of $95 \%$ with corresponding grade of $13 \%$. Chen et al. [16] used bio-coal as reductant for the carbothermic reduction of limonitic and saprolitic laterite ores at 
900-1400 ${ }^{\circ} \mathrm{C}(1173-1673 \mathrm{~K})$. They reported an increase in the nickel content of limonite from $1.47 \mathrm{wt} \%$ to $1.64 \mathrm{wt} \%$ after reduction at $1100{ }^{\circ} \mathrm{C}(1373 \mathrm{~K})$ and of saprolite from $3.43 \mathrm{wt} \%$ to 4.93 wt \% after reduction at $1200{ }^{\circ} \mathrm{C}(1473 \mathrm{~K})$. They reported the major phases observed after reductions but did not report the detailed metallization from their samples.

The effect of $\mathrm{Na}_{2} \mathrm{SO}_{4}$ on carbothermic reduction of laterite ore has also been investigated. Jiang et al. [17] tested a number of additives such as $\mathrm{Na}_{2} \mathrm{O}, \mathrm{S}, \mathrm{Na}_{2} \mathrm{~S}$ and $\mathrm{Na}_{2} \mathrm{SO}_{4}$. They reported that using $10 \mathrm{wt} \% \mathrm{~N}_{2} \mathrm{SO}_{4}$ and 2 wt \% coal for reduction at $1200{ }^{\circ} \mathrm{C}(1473 \mathrm{~K})$, result in $9.87 \%$ Ni grade with $91 \%$ recovery. They suggested that $\mathrm{Na}_{2} \mathrm{O}$ from the thermal dissociation of $\mathrm{Na}_{2} \mathrm{SO}_{4}$, formed nepheline phase $\left(\mathrm{Na}_{3} \mathrm{MgAl}\left(\mathrm{SiO}_{4}\right)_{2}\right)$ by reaction with silicate minerals. This low melting point phase was suggested to accelerate the mass transfer rate of metal and promote its growth. In relation to the effect of sulfur, it was suggested that the sulfur is enriched in the surface of the alloy and this can reduce the surface tension of the alloy and also promote its growth. Sulfur also can react with iron to form FeS and lowering the metallization of Fe. Rao et al. [18] used higher concentration of $\mathrm{Na}_{2} \mathrm{SO}_{4}$ (up to 20 wt \% ) and $\mathrm{CO}$ gas as reductant; and observed the same benefit of increased of Ni metallization and decreased of Fe metallization. They suggested that the optimum condition (Ni metallization $>90 \%$ ) in the presence of $20 \mathrm{wt} \% \mathrm{Na}_{2} \mathrm{SO}_{4}$ and using $\mathrm{CO} / \mathrm{N}_{2}$ mixture is reduction at $1000{ }^{\circ} \mathrm{C}(1273 \mathrm{~K})$ for $45 \mathrm{~min}$. Rao et al. [19] reported that the $20 \mathrm{wt} \% \mathrm{Na}_{2} \mathrm{SO}_{4}$ addition increases the average alloy particle size from $7.4 \mu \mathrm{m}$ to $48.6 \mu \mathrm{m}$. Rao et al. [18,19] proposed a different reaction mechanism of laterite reduction enhancement; it was suggested that $\mathrm{Na}_{2} \mathrm{SO}_{4}$ readily reduced to $\mathrm{Na}_{2} \mathrm{~S}$ rather than $\mathrm{Na}_{2} \mathrm{O}$ as suggested by Jiang et al. [17] which then react with $\mathrm{FeO}$ and $\mathrm{SiO}_{2}$ to form $\mathrm{FeS}$ and sodium silicate. This sodium silicate then reacts with $(\mathrm{Mg}, \mathrm{Fe}, \mathrm{Ni})_{2} \mathrm{SiO}_{4}$, liberating the nickel and iron.

Although there have been many studies on the carbothermic reduction of nickel laterite, the majority these studies had focused mainly on limonitic laterite ore and only limited studies on the saprolitic laterite ore are available. Understanding the fundamental for obtaining the optimum conditions for extraction of nickel is important as these conditions are different for limonitic and saprolitic ores. In terms of thermodynamic modeling, there are only few studies of carbothermic reduction of saprolitic ore. Only limited elements and phases were included; and majority of the condensed phases were assumed to behave ideally (with the exception of the Fe, $\mathrm{Ni}$ alloy) in these studies [18-21]. Minor impurity elements were also not included such as $\mathrm{Cr}, \mathrm{Mn}$, and Al. Systematic and comprehensive thermodynamic assessments and modeling are carried out in the present study to evaluate the effect of key parameters such as temperature, oxygen potential, and reductant amount during the carbothermic reduction of saprolitic laterite using carbon and low-rank coals, particularly on the phases formation and transformation and also on the metallization. The effect of additive such as $\mathrm{S}, \mathrm{FeS}, \mathrm{Na}_{2} \mathrm{~S}, \mathrm{Na}_{2} \mathrm{SO}_{4}$, and $\mathrm{CaSO}_{4}$ are also evaluated in this work. This work is part of broader study on the development of solar-assisted carbothermic reduction of laterite.

\section{Methodology}

\subsection{Laterite Materials}

Nickeliferous (saprolitic) laterite ore obtained from region of Southeast Sulawesi (Pomala) in Indonesia was utilized for the purpose of thermodynamic assessment and experimental works in the current study. The composition of the laterite is shown in Table 1, presented in the form of elemental and assumed oxides compositions. The values inside bracket are normalized values, calculated by dividing the wt $\%$ of individual oxide by the total wt \% of all oxides multiplying by 100 and excluding moisture and crystal waters. It can be seen that the main elements of the ore are iron, silicon, and magnesium. The concentration of the nickel is $1.71 \mathrm{wt} \%$. The composition also suggests that the ore is a saprolitic laterite with high concentration of iron. 
Table 1. Chemical composition of nickeliferous laterite ore used in the present study, in wt \%.

\begin{tabular}{|c|c|c|c|c|c|c|c|c|c|}
\hline \multirow{2}{*}{$\begin{array}{c}\text { Elemental } \\
\text { Composition, wt \% }\end{array}$} & $\mathbf{N i}$ & Co & $\mathrm{Fe}$ & $\mathbf{M g}$ & $\mathrm{Cr}$ & Mn & $\mathrm{Si}$ & Al & Sum \\
\hline & 1.71 & 0.056 & 18.93 & 8.08 & 0.128 & 0.43 & 11.50 & 1.02 & 41.85 \\
\hline \multirow{2}{*}{$\begin{array}{l}\text { Assumed Oxides } \\
\text { Composition, wt \% }\end{array}$} & $\mathrm{NiO}$ & $\mathrm{CoO}$ & $\mathrm{Fe}_{2} \mathrm{O}_{3}$ & $\mathrm{MgO}$ & $\mathrm{Cr}_{2} \mathrm{O}_{3}$ & $\mathrm{MnO}$ & $\mathrm{SiO}_{2}$ & $\mathrm{Al}_{2} \mathrm{O}_{3}$ & Sum \\
\hline & $\begin{array}{c}2.18 \\
(3.11)\end{array}$ & $\begin{array}{c}0.071 \\
(0.102)\end{array}$ & $\begin{array}{c}27.07 \\
(38.66)\end{array}$ & $\begin{array}{c}13.4 \\
(19.13)\end{array}$ & $\begin{array}{c}0.187 \\
(0.267)\end{array}$ & $\begin{array}{c}0.555 \\
(0.793)\end{array}$ & $\begin{array}{c}24.64 \\
(35.18)\end{array}$ & $\begin{array}{c}1.93 \\
(2.76)\end{array}$ & $\begin{array}{c}70.03 \\
(100.00)\end{array}$ \\
\hline
\end{tabular}

* The values inside bracket are normalized.

Lignite (brown coal) and sub-bituminous coals were used in the current study as reductants for the carbothermic reaction; and their chemical compositions are presented in Table 2. The concentrations of the fixed carbon are $36.9 \mathrm{wt} \%$ and $24.3 \mathrm{wt} \%$; while the sulfur are $0.91 \mathrm{wt} \%$ and $1.94 \mathrm{wt} \%$ for the sub-bituminous and lignite, respectively. Tables 3 and 4 show the compositions of the ashes in the sub-bituminous and lignite; and the volatile matters in the coals, respectively.

Table 2. Chemical composition of lignite and sub-bituminous coal, in wt \%.

\begin{tabular}{ccccccc}
\hline Coal Rank & $\begin{array}{c}\text { Fixed } \\
\text { Carbon }\end{array}$ & Sulfur & Moisture & $\begin{array}{c}\text { Volatile } \\
\text { Matter }\end{array}$ & Ash & $\begin{array}{c}\text { Calorific Value } \\
\text { (MJ/kg) }\end{array}$ \\
\hline Sub-bituminous & 36.9 & 0.91 & 14.4 & 36.3 & 14.4 & 25.3 \\
Lignite & 24.3 & 1.94 & 10.5 & 45.6 & 17.2 & 18.9 \\
\hline
\end{tabular}

Table 3. Chemical composition of ashes in lignite and sub-bituminous coal, in wt \%.

\begin{tabular}{ccccccccccccc}
\hline $\begin{array}{c}\text { Ash } \\
\text { Composition }\end{array}$ & $\mathrm{SiO}_{2}$ & $\mathrm{Al}_{2} \mathbf{O}_{3}$ & $\mathrm{Fe}_{2} \mathbf{O}_{3}$ & $\mathbf{M g O}$ & $\mathbf{C a O}$ & $\mathbf{N a}_{\mathbf{2}} \mathbf{O}$ & $\mathbf{K}_{\mathbf{2}} \mathbf{O}$ & $\mathbf{T i O}_{2}$ & $\mathbf{P}_{\mathbf{2}} \mathbf{O}_{\mathbf{5}}$ & $\mathbf{M n O}$ & $\mathbf{S O}_{3}$ & $\mathbf{S}$ \\
\hline Sub-bituminous & 56.9 & 23.8 & 10.0 & 1.2 & 3.9 & 0.3 & 1.2 & 1.2 & 0.5 & 0.1 & 0.0 & 0.7 \\
Lignite & 32.1 & 14.6 & 6.3 & 4.8 & 33.6 & 0.7 & 2.6 & 1.9 & 0.0 & 0.1 & 3.3 & 0.0 \\
\hline
\end{tabular}

Table 4. Chemical composition of volatile matters in the coal, in wt \%.

\begin{tabular}{cccccc}
\hline Volatile Matters & Carbon & Hydrogen & Nitrogen & Oxygen & Sulfur \\
\hline Sub-bituminous & 36.9 & 0.91 & 14.4 & 36.3 & 14.4 \\
\hline
\end{tabular}

For the purpose of the current study, reactions between coals and nickel laterite were evaluated. The nickel laterite was mixed with coals (with coals percentage of 1-10 wt \%) then the mixtures were reacted at temperatures of $900-1100{ }^{\circ} \mathrm{C}(1173-1373 \mathrm{~K})$. Other additives were also added to the mixture, such as $\mathrm{S}$ (up to $6 \mathrm{wt} \%$ ), $\mathrm{FeS}$ (up to $5 \mathrm{wt} \%$ ), $\mathrm{Na}_{2} \mathrm{~S}$ (up to $10 \mathrm{wt} \%$ ), $\mathrm{Na}_{2} \mathrm{SO}_{4}$ (up to $10 \mathrm{wt} \%$ ), and $\mathrm{CaSO}_{4}$ (up to $10 \mathrm{wt} \%$ ).

\subsection{Modeling Approach}

In the current work, the thermodynamic assessment and modeling were carried out using the thermochemical software FactSage 7.2 (Thermfact/CRCT, Montreal, QC, Canada) with the suitable optimized compound and solution databases. The following FactSage databases were used, FactPS (for pure compounds), FToxide (for solid and liquid oxide solutions), FTmisc (for liquid alloys and sulfides solution), and FSstel (for alloys). Standard thermochemical data compiled in JANAF and NBS thermochemical tables were used in FactSage. The sublattice/compound energy formalism solution model was used to model the solid alloys and solid sulfides. Liquid sulfides and liquid oxides were modeled using the modified quasichemical, while liquid alloys were modeled using $\mathrm{M}^{*} \mathrm{O}$ associate model [22].

The following analyses were carried out in the current work:

(1) The effect of reduction potential $\left(\mathrm{pO}_{2}\right)$ and temperatures $900-1100{ }^{\circ} \mathrm{C}(1173-1373 \mathrm{~K})$ on the phases formation and composition, including $(\mathrm{Fe}, \mathrm{Ni})$ alloy, i.e., metallization and nickel grade. 
(2) The effect $C$ and coal (sub-bituminous and lignite) addition (up to $10 \mathrm{wt} \%$ ) on the phase formation and composition at $1000{ }^{\circ} \mathrm{C}(1273 \mathrm{~K})$.

(3) The effect of additives $\mathrm{S}$ (up to $6 \mathrm{wt} \%$ ), $\mathrm{FeS}$ (up to $5 \mathrm{wt} \%$ ), $\mathrm{Na}_{2} \mathrm{~S}$ (up to $10 \mathrm{wt} \%$ ), $\mathrm{Na}_{2} \mathrm{SO}_{4}$ (up to $10 \mathrm{wt} \%$ ), and $\mathrm{CaSO}_{4}$ (up to $10 \mathrm{wt} \%$ ) at fixed $\mathrm{C}$ and at $1000{ }^{\circ} \mathrm{C}(1273 \mathrm{~K})$.

In the calculations, it was assumed that the moisture and crystal water in the laterite materials have already evaporated and decomposed. The ashes and volatile matters in the coals were included in the calculations following the compositions shown in the Tables 3 and 4 . The calculations were carried out assuming closed systems. The following elements (and associated compounds) were included in the thermodynamic calculations: $\mathrm{Ni}, \mathrm{Co}, \mathrm{Fe}, \mathrm{Mg}, \mathrm{Cr}, \mathrm{Mn}, \mathrm{Si}, \mathrm{Al}, \mathrm{C}, \mathrm{S}, \mathrm{Na}$, and $\mathrm{Ca}$. The following information was inputted into the Equilib module of the FactSage (where the coefficient represented the amount in g)

$$
\begin{aligned}
2.18 \mathrm{NiO}+27.07 \mathrm{Fe}_{2} \mathrm{O}_{3} & +13.4 \mathrm{MgO}+24.64 \mathrm{SiO}_{2}+1.93 \mathrm{Al}_{2} \mathrm{O}_{3}+0.071 \mathrm{CoO}+0.187 \mathrm{Cr}_{2} \mathrm{O}_{3} \\
& +0.555 \mathrm{MnO}+m \mathrm{C} \text { (or coals) }+n \text { additive }
\end{aligned}
$$

The amounts of $m$ and $n$ depend on the target concentrations of the carbon sources (or coal) and the additives, i.e., $\mathrm{S}, \mathrm{Na}_{2} \mathrm{~S}, \mathrm{Na}_{2} \mathrm{SO}_{4}$, and $\mathrm{CaSO}_{4}$.

\section{Results and Discussion}

\subsection{Effect of Temperature and Reduction Potential $\left(\mathrm{pO}_{2}\right)$ on Phases Formation}

To understand the general behavior of the saprolitic laterite under reducing conditions, equilibrium calculations were carried out for different oxygen potentials $\left(\mathrm{pO}_{2}=10^{-10}\right.$ to $\left.10^{-20} \mathrm{~atm}\right)$ and for temperatures $900{ }^{\circ} \mathrm{C}(1173 \mathrm{~K}), 1000{ }^{\circ} \mathrm{C}(1273 \mathrm{~K})$, and $1100{ }^{\circ} \mathrm{C}(1373 \mathrm{~K})$, and the results are presented in Figure 1. Figure $1 \mathrm{a}, \mathrm{c}, \mathrm{e}$ show the phases formation and change; while Figure $1 \mathrm{~b}, \mathrm{~d}$, f show the formation of solid solution of alloy as the reduction potential is increased.

It can be seen that at $900^{\circ} \mathrm{C}(1173 \mathrm{~K})$ and at mild reduction condition $\left(\mathrm{pO}_{2}\right.$ of approximately $10^{-10}$ $\mathrm{atm})$, the stable phases were predicted to be the group of olivine (forsterite- $\left.(\mathrm{Mg}, \mathrm{Fe}, \mathrm{Ni}, \mathrm{Mn}, \mathrm{Co})_{2} \mathrm{SiO}_{4}\right)$, ortho-pyroxene (enstatite- $\left.(\mathrm{Mg}, \mathrm{Fe}) \mathrm{SiO}_{3}\right)$, and spinel (magnetite- $(\mathrm{Fe}, \mathrm{Ni}, \mathrm{Mg}) \mathrm{O} .(\mathrm{Fe}, \mathrm{Cr}, \mathrm{Al})_{2} \mathrm{O}_{3}$ ), as shown in Figure 1a. All the nickel was predicted to be associated with the forsterite and magnetite with proportion of $47 \%$ and $53 \%$, respectively. As the reduction potential was increased, enstatite and magnetite were started to reduce and at the same point more forsterite was formed. This occurred further until cordierite- $\left(\mathrm{Mg}, \mathrm{Fe}_{2}\right)_{2} \mathrm{Al}_{4} \mathrm{Si}_{5} \mathrm{O}_{18}$ start to form. Once all the cordierite was reduced, the $(\mathrm{Fe}, \mathrm{Ni})$ alloy started to form, which happened approximately at $\mathrm{pO}_{2}$ lower than $10^{-15} \mathrm{~atm}$. At this point, more enstatite started to re-form. At high reduction potential $\left(\mathrm{pO}_{2} \sim 10^{-20} \mathrm{~atm}\right)$ as more $(\mathrm{Fe}, \mathrm{Ni})$ alloy was forming, the enstatite started to reduce again and cordierite re-appear, along with rhodonite- $(\mathrm{Mg}, \mathrm{Fe}, \mathrm{Mn}) \mathrm{SiO}_{3}$ and tridymite- $\mathrm{SiO}_{2}$. These results presented, in general, agree with the thermodynamic assessment carried out by Rhamdhani et al. [11] for a mixture of saprolitic and limonitic laterite ores at lower temperature range of $650-850{ }^{\circ} \mathrm{C}(923-1123 \mathrm{~K})$. Figure $1 \mathrm{~b}$ shows the details of the composition/amount of the solid ( $\mathrm{Fe}, \mathrm{Ni}$ ) alloy with all the constituents. It can be seen that at approximately $\mathrm{pO}_{2}=10^{-15} \mathrm{~atm}$, the alloy started to form. The modeling results suggested that $\mathrm{Ni}$, $\mathrm{Fe}$, and $\mathrm{Co}$ co-precipitated at the same point, nevertheless more nickel formed compared to Fe and Co. Thus, at this initial point, the alloy was very rich in $\mathrm{Ni}$. As the reduction potential was increased, more alloy was formed and more iron and cobalt went to the alloy, reducing the concentration of the $\mathrm{Ni}$. The reduction of the saprolitic laterite at $900^{\circ} \mathrm{C}(1173 \mathrm{~K})$ can be broadly explained through the general steps explained in the Equations (2) to (5) below (increasing reduction potential as we move from Equations (2) to (5))

$$
\text { enstatite }+ \text { magnetite } \stackrel{\text { co-reduction }}{\longrightarrow} \text { forsterite }
$$


forsterite $\rightarrow(\mathrm{Fe}, \mathrm{Ni})$ alloy + re-formation of enstatite

enstatite + forsterite $\stackrel{\text { co-reduction }}{\longrightarrow}$ cordierite + rhodonite + tridymite
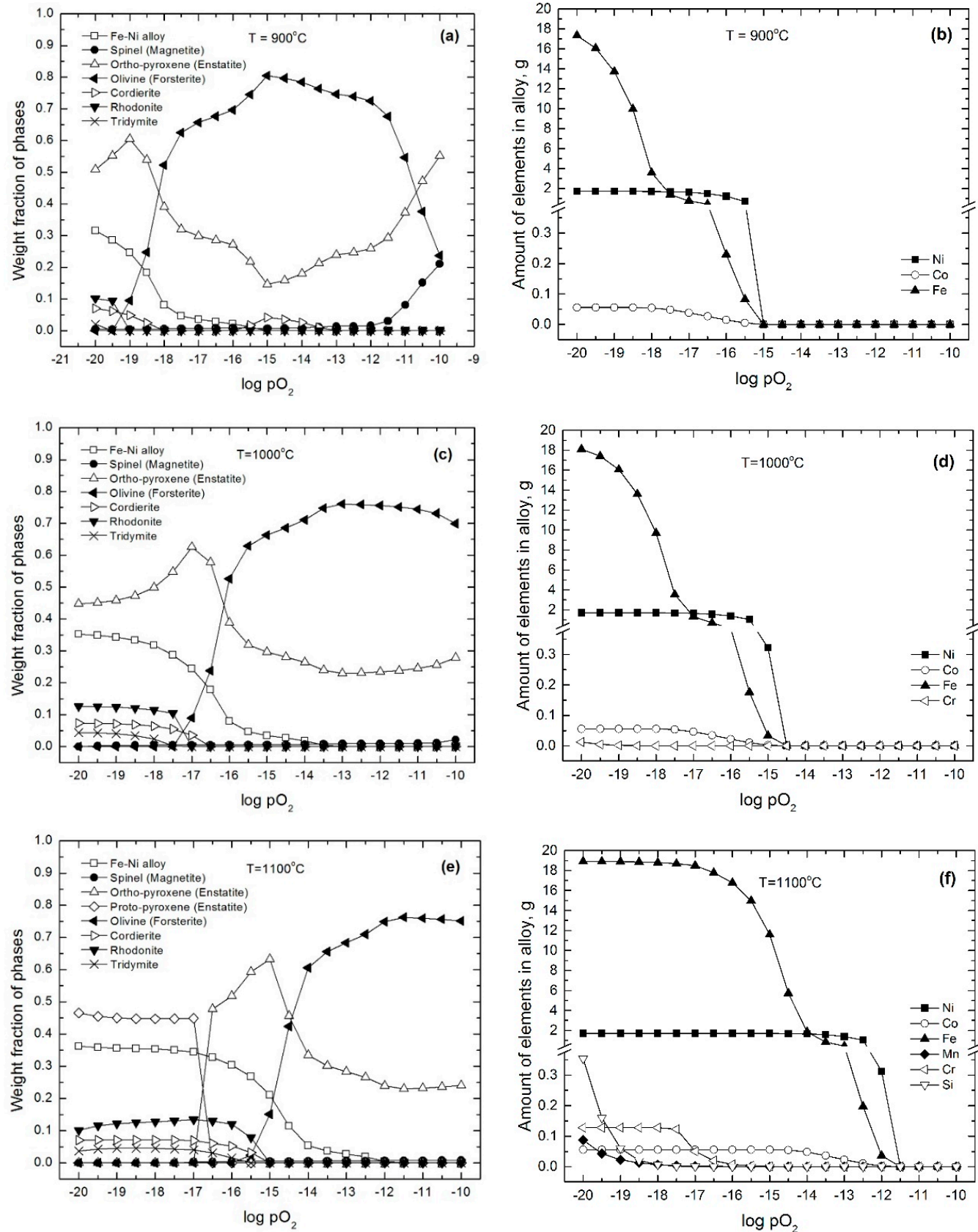

Figure 1. Thermodynamic predictions of the phases stability and formation in the saprolitic laterite ore at different reduction potentials $\left(\mathrm{pO}_{2}\right)$ and temperature. (a) phases composition at $900{ }^{\circ} \mathrm{C}(1173 \mathrm{~K}),\left(\right.$ b) $\mathrm{Fe}-\mathrm{Ni}$ alloy composition at $900{ }^{\circ} \mathrm{C}(1173 \mathrm{~K})$, (c) phases composition at $1000{ }^{\circ} \mathrm{C}(1273 \mathrm{~K})$, (d) Fe-Ni alloy composition at $1000{ }^{\circ} \mathrm{C}(1273 \mathrm{~K})$, (e) phases composition at $1100{ }^{\circ} \mathrm{C}(1373 \mathrm{~K})$, and (f) Fe-Ni alloy composition at $1100{ }^{\circ} \mathrm{C}(1373 \mathrm{~K})$. Legend: spinel (magnetite- $\left.(\mathrm{Fe}, \mathrm{Ni}, \mathrm{Mg}) \mathrm{O} .(\mathrm{Fe}, \mathrm{Cr}, \mathrm{Al})_{2} \mathrm{O}_{3}\right)$; ortho/proto-pyroxene (enstatite- $(\mathrm{Mg}, \mathrm{Fe}) \mathrm{SiO}_{3}$ ); olivine (forsterite- $\left.(\mathrm{Mg}, \mathrm{Fe}, \mathrm{Ni}, \mathrm{Mn}, \mathrm{Co})_{2} \mathrm{SiO}_{4}\right)$; cordierite- $(\mathrm{Mg}, \mathrm{Fe})_{2} \mathrm{Al}_{4} \mathrm{Si}_{5} \mathrm{O}_{18}$; rhodonite- $(\mathrm{Mg}, \mathrm{Fe}, \mathrm{Mn}) \mathrm{SiO}_{3}$; tridymite- $-\mathrm{SiO}_{2}$. 
Figure $1 \mathrm{c}, \mathrm{d}$ show the predicted results at temperature $1000{ }^{\circ} \mathrm{C}(1273 \mathrm{~K})$. The general trend in the reduction behavior of the saprolitic laterite was found to be similar to those at $900{ }^{\circ} \mathrm{C}(1173 \mathrm{~K})$. The reduction, however, can be carried out at higher oxygen potential (lower reduction potential). Unlike the case of reduction at $900{ }^{\circ} \mathrm{C}(1173 \mathrm{~K})$, formation of cordierite at intermediate oxygen potential was not observed, i.e., step described in Equation (4). (Fe, Ni) alloy was observed to form at higher oxygen potential of $\mathrm{pO}_{2}=10^{-14.5} \mathrm{~atm}$. It was also observed that at $\mathrm{pO}_{2}<10^{-18} \mathrm{~atm}$, all $\mathrm{Co}$ and $\mathrm{Ni}$ are reported to the alloy phase. After all the forsterite was reduced (approximately at $\mathrm{pO}_{2}=10^{-17.5}$ $\mathrm{atm})$, enstatite started to transform to cordierite, rhodonite, and tridymite. Thus, the reduction of the saprolitic laterite at $1000{ }^{\circ} \mathrm{C}(1273 \mathrm{~K})$ can generally be described by Equations (2), (3), and (5) only.

The reduction behavior at $1100{ }^{\circ} \mathrm{C}(1373 \mathrm{~K})$ was found to also be similar, in particular to that of at $1000^{\circ} \mathrm{C}(1273 \mathrm{~K})$, as shown in Figure 1e,f. At $\mathrm{pO}_{2}$ lower than $10^{-16.5} \mathrm{~atm}$, however, proto-pyroxene was observed as opposed to ortho-pyroxene. Proto-pyroxene is just a polymorph of the Mg-rich ortho-pyroxenes (enstatite) which is stable at high temperatures. At $1100{ }^{\circ} \mathrm{C}(1373 \mathrm{~K})$, the alloy was found to start form at a moderately low reduction potential of $\mathrm{pO}_{2}=10^{-11.5} \mathrm{~atm}$. All Co and Ni reported to the alloy phase at $\mathrm{pO}_{2}<10^{-15} \mathrm{~atm}$. $\mathrm{Cr}$, $\mathrm{Si}$, and $\mathrm{Mn}$ started to report to the alloy phase at $\mathrm{pO}_{2}<10^{-16} \mathrm{~atm}, \mathrm{pO}_{2}<10^{-18} \mathrm{~atm}$, and $\mathrm{pO}_{2}<10^{-18.5} \mathrm{~atm}$, respectively. The reduction at $1100{ }^{\circ} \mathrm{C}(1373$ $\mathrm{K})$, can be generally described by Equations (2), (3), and (5).

Figure 2a,b show the thermodynamic predictions of the metals recovery and nickel grade from the reduction of the saprolitic laterite ore at temperatures $900{ }^{\circ} \mathrm{C}(1173 \mathrm{~K})$ to $1100{ }^{\circ} \mathrm{C}(1373 \mathrm{~K})$ and $\mathrm{pO}_{2}$ $=10^{-10}$ to $10^{-20} \mathrm{~atm}$. In the context of the current discussion, the metals recovery was defined as the ratio of the amount (in weight) of $\mathrm{Fe}+\mathrm{Ni}+\mathrm{Co}$ at given condition to the total $\mathrm{Fe}+\mathrm{Ni}+\mathrm{Co}$ available in the saprolitic ore, multiplied by $100 \%$. Other trace elements-such as $\mathrm{Mn}, \mathrm{Cr}$, and $\mathrm{Si}$-were not included due to their small amount and the fact that these were formed at very low oxygen potential. The nickel grade was defined as the amount of nickel divided by the amount of metals at that given condition multiplied by $100 \%$.
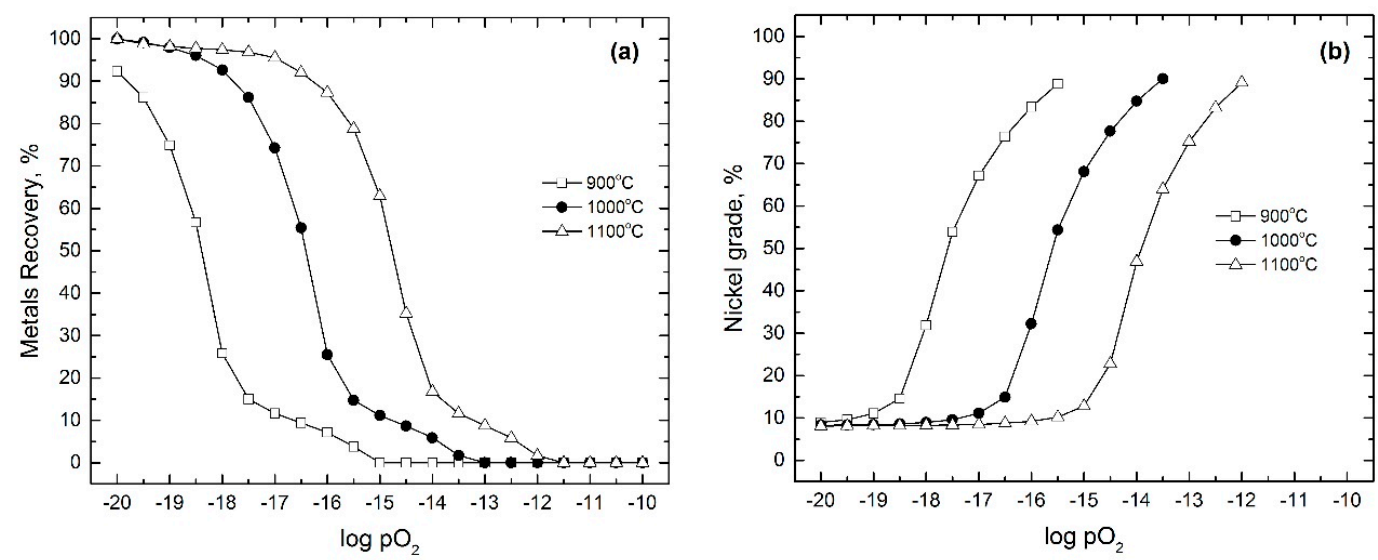

Figure 2. Thermodynamic predictions on (a) the metals recovery and (b) nickel grade of the alloy resulted from the reduction of saprolitic laterite ore at different reduction potentials $\left(\mathrm{pO}_{2}\right)$ and temperatures.

It can be seen from Figure 2a, that at the same oxygen potential, higher metals recovery can be obtained when the reduction is carried out at higher temperature. To illustrate this, the metals recoveries at $\mathrm{pO}_{2}=10^{-16} \mathrm{~atm}$ were found to be $7.1 \%, 25.5 \%, 87.3 \%$, at $900{ }^{\circ} \mathrm{C}(1173 \mathrm{~K}), 1000{ }^{\circ} \mathrm{C}(1273$ $\mathrm{K})$, and $1100{ }^{\circ} \mathrm{C}(1373 \mathrm{~K})$, respectively. The metals recovery, however, is inversely proportional to the nickel grade. This mainly because as more metal/alloy is formed more iron (and Co) report to it; and this occurs further beyond the point when all the nickel exist in the ore has reported to the alloy. For example, at the same $\mathrm{pO}_{2}$ of $10^{-16} \mathrm{~atm}$, the nickel grades were found to be $83.4 \%, 32.2 \%$, $9.2 \%$, for reductions carried out at $900{ }^{\circ} \mathrm{C}(1173 \mathrm{~K}), 1000{ }^{\circ} \mathrm{C}(1273 \mathrm{~K})$, and $1100{ }^{\circ} \mathrm{C}(1373 \mathrm{~K})$, respectively. Therefore, when the main purpose for the reduction of the saprolitic laterite ore is for recovering nickel 
as individual nickel, one should consider the reduction condition that balance the metals recovery and nickel grade. This way, the alloy that is formed can be further processed through hydrometallurgy route (leaching and precipitation) for nickel extraction without much difficulties (excess Fe is known to complicate the process).

\subsection{Effect of $\mathrm{C}$ and Coals Concentration on Phases Formation at $1000^{\circ} \mathrm{C}(1273 \mathrm{~K})$}

The phase transformation behavior of compounds and metals which are formed during carbothermic reduction of lateritic nickel saprolite ore using different types of carbon-based reducing agents, namely carbon, sub-bituminous, and lignite was evaluated. The high-rank carbon reductant used in this simulation contains no sulfur, while the sub-bituminous and lignite contain sulfur as much as $0.91 \mathrm{wt} \%$ and $1.94 \mathrm{wt} \%$, respectively.

Figure 3 shows the thermodynamic calculation predictions of the behavior of several compounds contained in saprolite nickel ore during the carbothermic process at temperatures of $1000{ }^{\circ} \mathrm{C}(1273 \mathrm{~K})$, namely spinel (magnetite, $(\mathrm{Fe}, \mathrm{Ni}, \mathrm{Mg}) \mathrm{O} .(\mathrm{Fe}, \mathrm{Cr}, \mathrm{Al})_{2} \mathrm{O}_{3}$ ), ortho-pyroxene (enstatite, $\left.(\mathrm{Mg}, \mathrm{Fe}) \mathrm{SiO}_{3}\right)$, olivine (forsterite, $(\mathrm{Mg}, \mathrm{Fe}, \mathrm{Ni}, \mathrm{Mn}, \mathrm{Co})_{2} \mathrm{SiO}_{4}$ ).
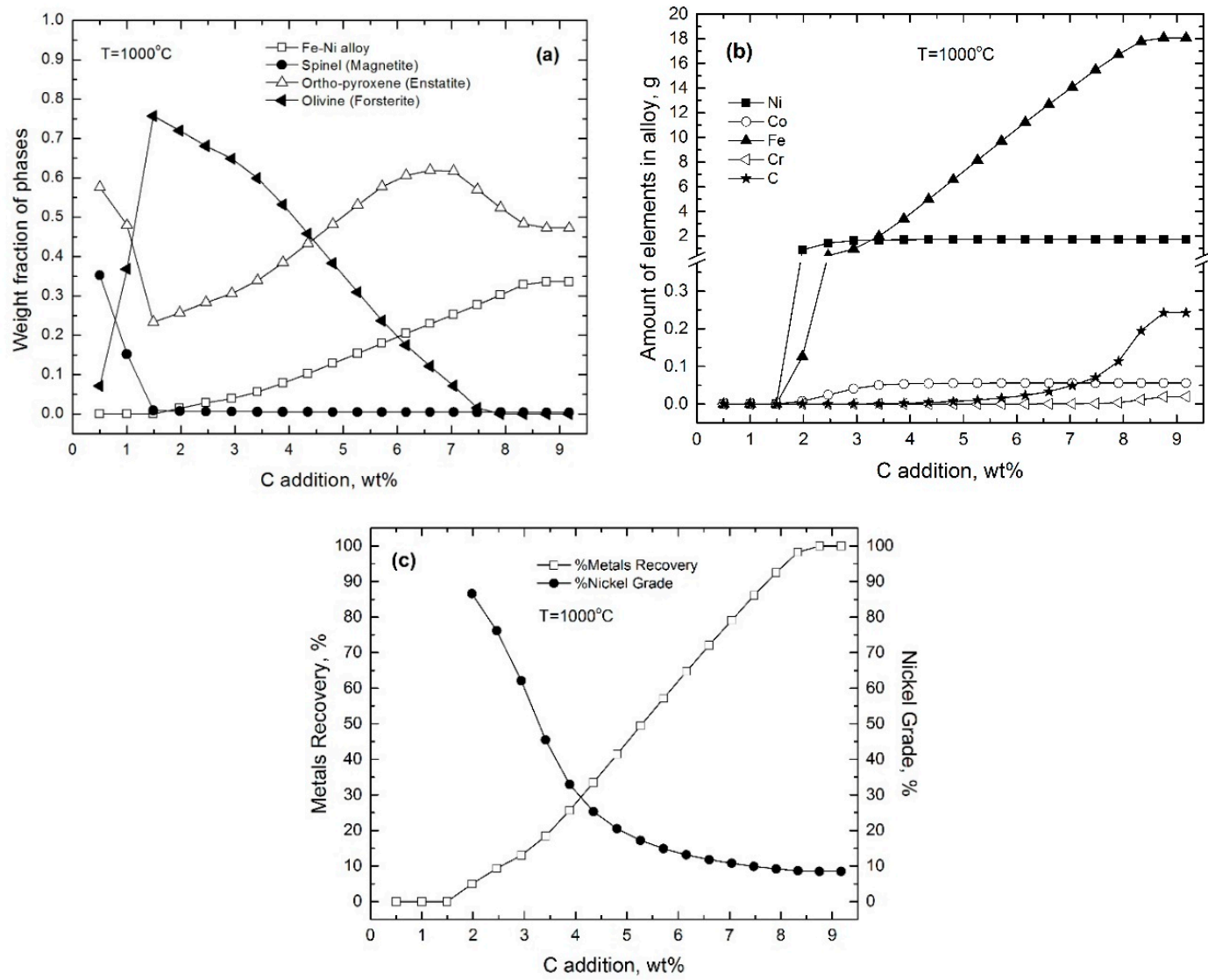

Figure 3. Thermodynamic predictions on (a) the condensed phases stability and formation (presented in weight fraction), (b) the amount of metals (and C) in the (Fe, Ni) alloy, and (c) the total metals recovery and nickel grade, for carbothermic reduction of saprolitic laterite at different carbon addition $(0.5 \mathrm{wt} \% \mathrm{C}$ to $9 \mathrm{wt} \% \mathrm{C})$ at $1000{ }^{\circ} \mathrm{C}(1273 \mathrm{~K})$. Legend: spinel (magnetite- $\left.(\mathrm{Fe}, \mathrm{Ni}, \mathrm{Mg}) \mathrm{O} .(\mathrm{Fe}, \mathrm{Cr}, \mathrm{Al})_{2} \mathrm{O}_{3}\right)$; ortho-pyroxene (enstatite- $\left.(\mathrm{Mg}, \mathrm{Fe}) \mathrm{SiO}_{3}\right)$; olivine (forsterite- $\left.(\mathrm{Mg}, \mathrm{Fe}, \mathrm{Ni}, \mathrm{Mn}, \mathrm{Co})_{2} \mathrm{SiO}_{4}\right)$.

Figure $3 a$ shows the effect of carbon addition up to $1.5 \mathrm{wt} \%$ at temperature of $1000{ }^{\circ} \mathrm{C}(1273 \mathrm{~K})$ which resulted in the complete decomposition of magnetite and partial decomposition of enstatite content up to $0.2 \mathrm{wt}$ fraction, and at the same time the formation of olivine up to $0.75 \mathrm{wt}$ fraction. Addition of carbon by more than $1.5 \%$ was predicted to produce $(\mathrm{Fe}, \mathrm{Ni})$ metal alloy. The formation of 
(Fe-Ni) by increasing $\mathrm{C}$ levels by $1.5-8 \%$ was accompanied by the reformation of enstatite. This is in accordance with the reaction stages predicted earlier in Equations (2) and (3). The formation of (Fe, $\mathrm{Ni}$ ) metal alloys was predicted to reach maximum with the carbon addition of $8.5 \%$. Meanwhile, the peak formation of enstatite was predicted at carbon addition range of 6-7 wt \%.

The phase transformation of metal is illustrated in Figure $3 \mathrm{~b}$ which showing the calculated amount of metal elements and carbon formed along with the addition of carbon during the carbothermic process at $1000{ }^{\circ} \mathrm{C}(1273 \mathrm{~K})$. Addition of carbon as much as $2 \mathrm{wt} \%$ was predicted to be able to produce $\mathrm{Ni}$ metal entirely. It was observed that the amount of $\mathrm{Ni}$ formed reaches $1.7 \mathrm{~g}$, which is the mass of nickel contained in the ore, while the iron has not been fully formed. Comparing the formation of nickel and iron in the range of addition of carbon as much as $2-3.5 \mathrm{wt} \%$, the formation of nickel metal was predicted to be more dominant. Addition of more than 3.5-8.7 wt \% carbon would produce iron metal entirely from its content in the feed ore. Cobalt began to form with the addition of more than $2 \mathrm{wt} \%$ carbon. By comparing all of the mass of metals it can be observed that the grade of nickel in metal alloys decreases with increasing carbon addition. The pick-up of carbon to the metal was also predicted from the simulation by addition of carbon of more than $7 \mathrm{wt} \%$.

Figure $3 \mathrm{c}$ shows the thermodynamic predictions of metals recovery compared to the nickel metal grade, with the addition of different amount of carbon at $1000{ }^{\circ} \mathrm{C}(1273 \mathrm{~K})$. Metals alloy was predicted to form from the carbothermic reaction at $1000{ }^{\circ} \mathrm{C}(1273 \mathrm{~K})$ with the addition of carbon more than $1.5 \mathrm{wt} \%$. The formation of this metal achieves maximum recovery with the addition of carbon up to $8.5 \mathrm{wt} \%$. However, the nickel grade was predicted to decrease with addition of carbon because other metals such as iron and cobalt also begin to form and report to the alloy. From this figure, it can be also predicted that the lowest nickel grade is about $8-9 \%$ at higher carbon addition. It also shows that the optimal carbon addition, by considering optimum metals recovery and the nickel grade, is about $4 \mathrm{wt} \%$ carbon addition. Furthermore, the effect of carbon in next part of simulation will refer to this optimal point, i.e., $4 \mathrm{wt} \%$ carbon addition.

Generally, for carbothermic reduction of saprolite at $1000{ }^{\circ} \mathrm{C}(1273 \mathrm{~K})$ using $\mathrm{C}$, the current thermodynamic study suggested that the nickel grade and nickel recovery are decreasing and increasing, respectively, with increasing of $C$ addition. This is in agreement with previous modeling study by Forster et al. (2016) whom carried out calculations for saprolite carbothermic reduction [15]. At $1000{ }^{\circ} \mathrm{C}(1273 \mathrm{~K})$, Forster et al. (2016) reported that the nickel recovery was increased from $60 \%$ to $99 \%$ when $\mathrm{C}$ was added from $2.25 \mathrm{wt} \%$ to $4 \mathrm{wt} \%$; while the nickel grade was decreased from $56 \%$ to $12 \%$ [15]. The current study predicted the increase of nickel recovery from $84 \%$ to $99.4 \%$ when C was added from $2.5 \mathrm{wt} \%$ to $3.9 \mathrm{wt} \%$ at $1000{ }^{\circ} \mathrm{C}(1273 \mathrm{~K})$. The nickel grade was predicted to decrease from $76.2 \%$ to $33 \%$ over the same range of $C$ addition and temperature. The same trend was also predicted for carbothermic reduction of limonite as reported by Pickles et al. (2014) [12]. The nickel grade and recovery were reported to decrease and increase, respectively, with increasing of carbon addition.

The effect of sub bituminous addition as reducing agent, containing fixed carbon of $36.9 \mathrm{wt} \%$ and sulfur of $0.91 \mathrm{wt} \%$ on condensed phases and metal formation behavior were simulated thermodynamically and the results are shown in Figure $4 \mathrm{a}-\mathrm{d}$ at reaction temperature of $1000{ }^{\circ} \mathrm{C}(1273 \mathrm{~K})$. Figure 4a illustrates that the addition of sub-bituminous up to $2 \mathrm{wt} \%$ could significantly reduce the magnetite and enstatite. The addition of sub-bituminous up to $2 \mathrm{wt} \%$ promoted the formation of forsterite at maximum fraction of 0.75 . The forsterite was predicted to gradually decompose with higher addition of sub-bituminous beyond $2 \mathrm{wt} \%$. Addition of sub-bituminous of about $9.5 \mathrm{wt} \%$ was predicted to produce maximum fraction of the enstatite in the condensed phases. The weight fraction of (Fe,Ni) alloy was predicted to increase in accordance with sub-bituminous addition from $2 \mathrm{wt} \%$. (Fe,Ni) alloy formation was observed to increase with increasing of sub-bituminous addition, e.g., the weight fraction of 0.25 of alloy was achieved by addition of sub-bituminous as much as $10 \mathrm{wt} \%$. (Fe,Ni)S was observed to form from the simulation prediction at $2 \mathrm{wt} \%$ addition of sub-bituminous. The amount was very small, but was found to increase with increasing sub-bituminous addition. An amount of (Fe,Ni)S of $0.24 \mathrm{~g}$ (equivalent to 0.004 fraction) was predicted by addition of sub-bituminous of $10 \mathrm{wt} \%$. 

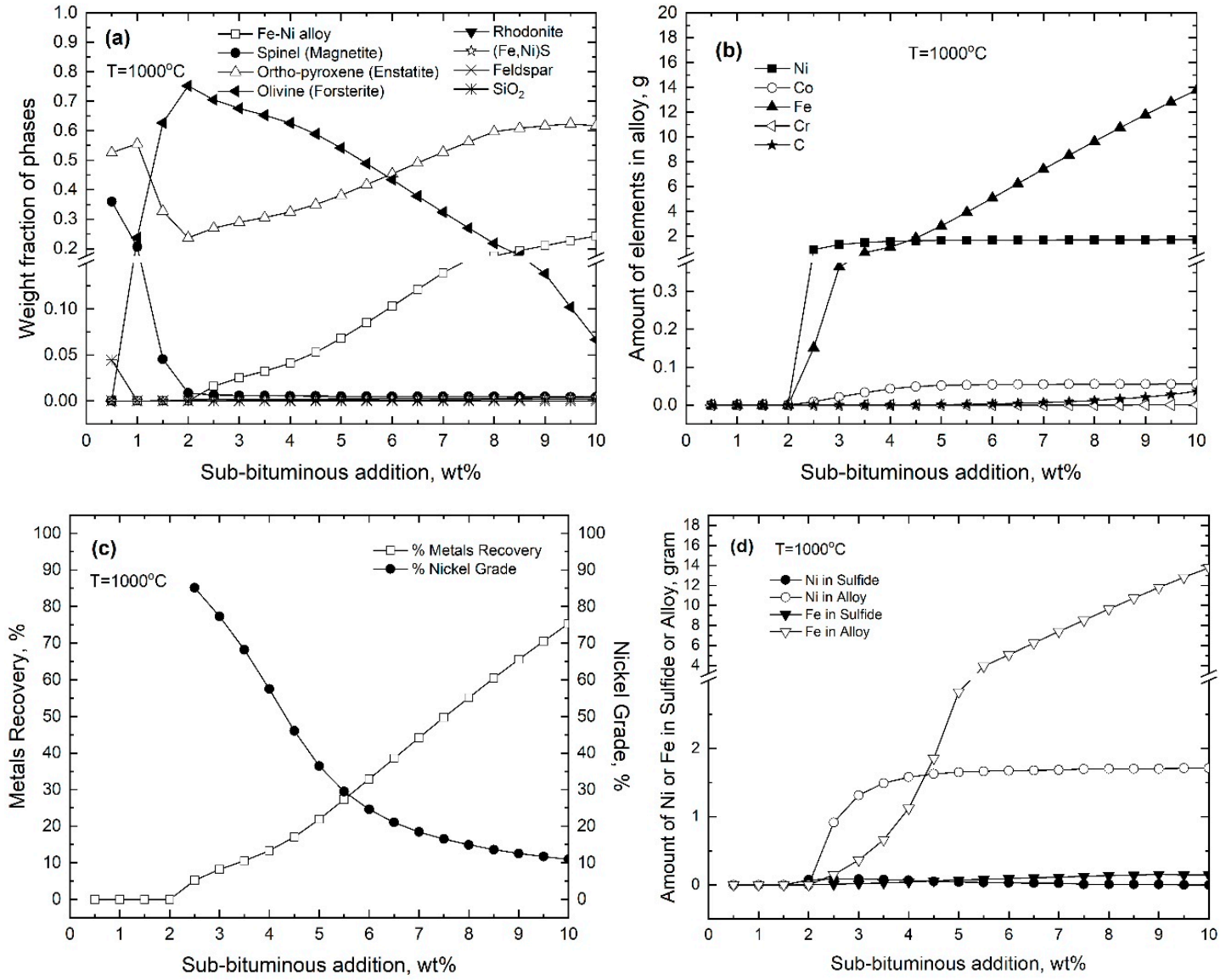

Figure 4. Thermodynamic predictions on (a) the condensed phases stability and formation (presented in weight fraction), (b) the amount of metals (and C) in the (Fe,Ni) alloy, (c) the total metals recovery and nickel grade, and (d) the comparison of $\mathrm{Ni}$ and $\mathrm{Fe}$ in sulfide and alloy; for carbothermic reduction of saprolitic laterite at different sub-bituminous coal addition (0.5 wt \% to $10 \mathrm{wt} \%)$ at $1000{ }^{\circ} \mathrm{C}(1273 \mathrm{~K})$. Legend: spinel (magnetite- $\left.(\mathrm{Fe}, \mathrm{Ni}, \mathrm{Mg}) \mathrm{O} .(\mathrm{Fe}, \mathrm{Cr}, \mathrm{Al})_{2} \mathrm{O}_{3}\right)$; ortho/proto-pyroxene (enstatite- $\left.(\mathrm{Mg}, \mathrm{Fe}) \mathrm{SiO}_{3}\right)$; olivine (forsterite- $\left.(\mathrm{Mg}, \mathrm{Fe}, \mathrm{Ni}, \mathrm{Mn}, \mathrm{Co})_{2} \mathrm{SiO}_{4}\right)$; cordierite- $\left(\mathrm{Mg}, \mathrm{Fe}_{2}{ }_{2} \mathrm{Al}_{4} \mathrm{Si}_{5} \mathrm{O}_{18}\right.$; rhodonite- $(\mathrm{Mg}, \mathrm{Fe}, \mathrm{Mn}) \mathrm{SiO}_{3}$, tridymite- $\mathrm{SiO}_{2}$.

The calculations also predicted formation of very small amounts of cordierite, feldspar, rhodonite, and pseudobrokite towards high addition ( $>9$ wt \%) of sub-bituminous coal at $1000{ }^{\circ} \mathrm{C}(1273 \mathrm{~K})$.

Compared to the case of carbon/coke addition, the utilization of sub-bituminous was predicted to result in little carbon pick-up into the metal, i.e., $0.24 \mathrm{wt} \%$ of $\mathrm{C}$ at about $10 \mathrm{wt} \%$ addition. The trend of the formation of metals $\mathrm{Ni}, \mathrm{Fe}, \mathrm{Co}$, and $\mathrm{Cr}$ tends to be similar to the case of carbothermic reduction using carbon reducing agent only, which have a relatively higher grade. As shown in Figure $4 \mathrm{~b}$ metal formation began with the formation of Ni metal followed by Fe when the sub-bituminous was added by more than $2 \mathrm{wt} \%$. Co was predicted to form with the addition of sub-bituminous of more than $2.5 \mathrm{wt} \%$. Furthermore, the addition of $4 \mathrm{wt} \%$ sub-bituminous can promote the formation of almost all Ni metal from the ore. Meanwhile, the addition of more than 4 wt \% sub-bituminous significantly increase the formation of Fe.

The utilization of sub-bituminous in carbothermic reaction at temperatures of $1000{ }^{\circ} \mathrm{C}(1273 \mathrm{~K})$ provided some influence on the metal recovery, compared to case of carbothermic reduction using carbon in the same addition range (Figure 4c). The metal recovery started to take place with an addition of more than $2 \mathrm{wt} \%$ and was yet to reach the peak at addition beyond $10 \mathrm{wt} \%$ sub-bituminous. The slight difference in the metal recovery was due to the formation of $(\mathrm{Fe}, \mathrm{Ni}) \mathrm{S}$. The decrease in nickel grade was observed with increasing of sub-bituminous addition, similarly to the case of carbon 
addition. Furthermore, the optimum point of metal recovery and nickel grade was found at the addition of about $5.5 \mathrm{wt} \%$ sub-bituminous with a nickel grade of around $30 \%$.

Figure $4 \mathrm{~d}$ shows the formation of $\mathrm{Ni}$ and Fe metals, which are represented by elemental masses, taking into account the presence of sulfur contained in sub-bituminous. With a sulfur content of $0.9 \mathrm{wt} \%$ in sub-bituminous, the formation of $(\mathrm{Fe}, \mathrm{Ni}) \mathrm{S}$ was observed beyond $2 \mathrm{wt} \%$ sub-bituminous addition.

The effect of lignite addition as an alternative reducing agent on saprolitic nickel laterite ore carbothermic reduction is shown in Figure 5a-d. The tendency of decomposition and formation of compounds and metals has similarities with the case of carbon/coke and sub-bituminous addition as the reducing agents. The behavior of decomposition of enstatite and magnetite compounds and formation of forsterite formed with addition of lignite up to $2 \mathrm{wt} \%$ is similar to that of a carbothermic process using higher carbon reducing agents (carbon/coke and sub-bituminous). Likewise, with the prediction of the phase transformation that occurs with the lignite addition of more than $2 \mathrm{wt} \%$. Figure $5 \mathrm{a}$ shows the decomposition of tridymite at lignite addition of less than $1 \mathrm{wt} \%$. Increasing the addition of lignite appeared to promote the formation of feldspar. The formation of liquid phase of $(\mathrm{Fe}, \mathrm{Ni})$ metal sulfide was also observed with the addition of lignite beyond $2 \mathrm{wt} \%$ at the reaction temperature of $1000{ }^{\circ} \mathrm{C}(1273 \mathrm{~K})$ and reached maximum at $10 \mathrm{wt} \%$ (0.63 g 0.01 fraction).
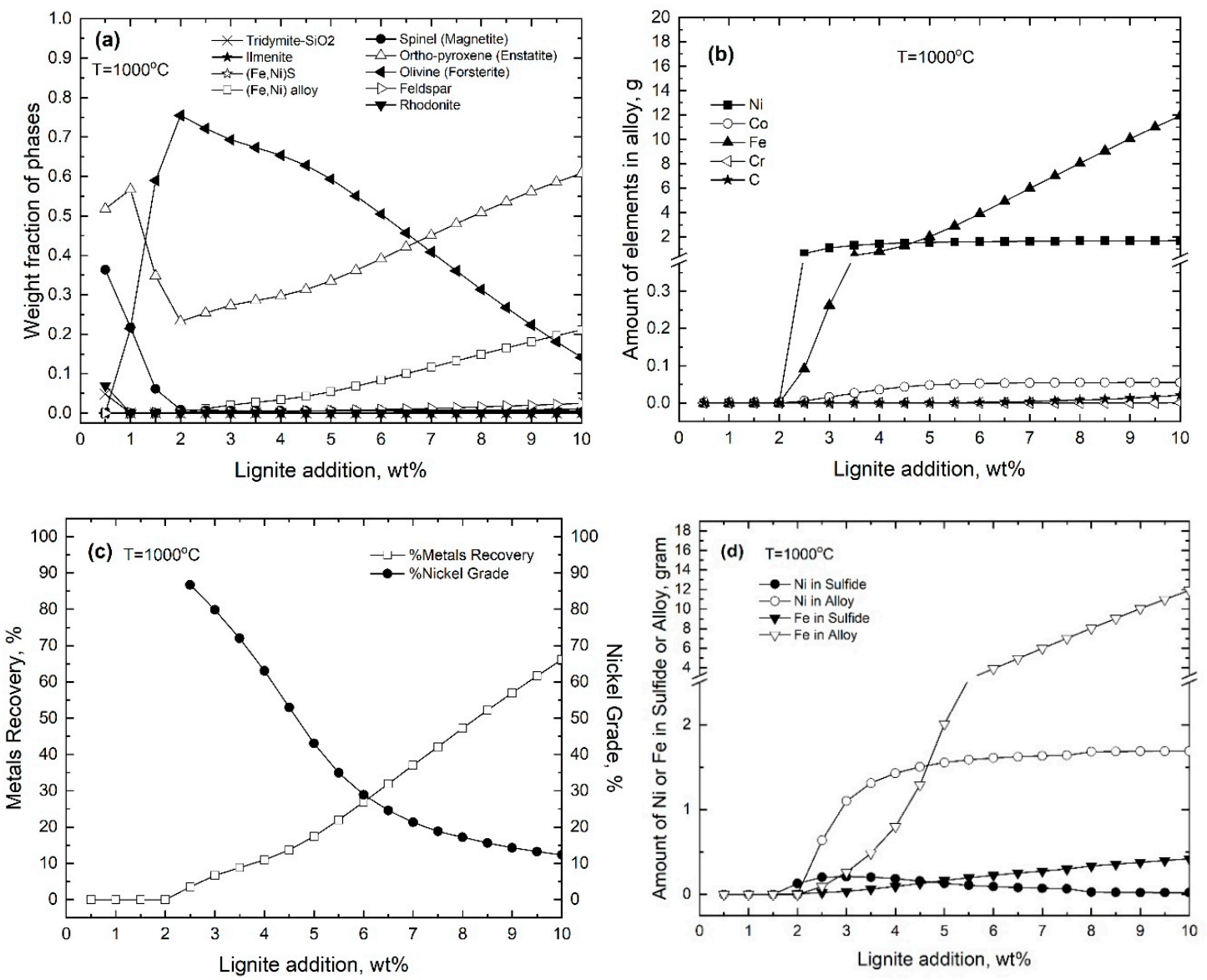

Figure 5. Thermodynamic predictions on (a) the condensed phases stability and formation (presented in weight fractio), (b) the amount of metals (and C) in the (Fe,Ni) alloy, (c) the total metals recovery and nickel grade, and (d) the comparison of $\mathrm{Ni}$ and $\mathrm{Fe}$ in sulfide and alloy; for carbothermic reduction of saprolitic laterite at different lignite coal addition $(0.5 \mathrm{wt} \%$ to $10 \mathrm{wt} \%)$ at $1000{ }^{\circ} \mathrm{C}(1273 \mathrm{~K})$. Legend: spinel (magnetite- $\left.(\mathrm{Fe}, \mathrm{Ni}, \mathrm{Mg}) \mathrm{O} .(\mathrm{Fe}, \mathrm{Cr}, \mathrm{Al})_{2} \mathrm{O}_{3}\right)$; ortho/proto-pyroxene (enstatite- $\left.(\mathrm{Mg}, \mathrm{Fe}) \mathrm{SiO}_{3}\right)$; olivine (forsterite- $\left.(\mathrm{Mg}, \mathrm{Fe}, \mathrm{Ni}, \mathrm{Mn}, \mathrm{Co})_{2} \mathrm{SiO}_{4}\right)$; cordierite- $(\mathrm{Mg}, \mathrm{Fe})_{2} \mathrm{Al}_{4} \mathrm{Si}_{5} \mathrm{O}_{18}$; rhodonite- $(\mathrm{Mg}, \mathrm{Fe}, \mathrm{Mn}) \mathrm{SiO}_{3}$, tridymite- $-\mathrm{SiO}_{2}$. 
In general, Figure $5 b$ shows the same tendency of the effect of lignite addition on the behavior of the formation of compounds and metal formation in a carbothermic reaction. It has similar phenomena as well as a reaction using higher carbon reducing agents (carbon and sub-bituminous). The tendency for the re-dissolution of carbon into the metal was observed to increase with increasing lignite addition and reaches a maximum of about $0.15 \mathrm{wt} \%$ at $10 \mathrm{wt} \%$ lignite addition.

Metal recovery behavior and its relationship to the nickel grade are shown in Figure 5c. In general, maximum metal recovery that can be achieved by carbon based reducing agents such as carbon, sub-bituminous and lignite (of maximum addition of up to $10 \%$ ) are $100 \%, 76 \%$, and $66 \%$, respectively. The reason mainly because of the total carbon concentration that can participate in the reaction to reduce the oxides into the metals is much less in the sub-bituminous and lignite. Figure $5 \mathrm{c}$ also shows the optimum point of metal recovery and the nickel grade that can be achieved at around $6 \mathrm{wt} \%$, compared to value obtained by using carbon/coke and sub-bituminous at $4 \mathrm{wt} \%$ and $5.5 \mathrm{wt} \%$, respectively.

Figure $5 \mathrm{~d}$ shows a similar trend with the reducing agents used previously namely carbon/coke and sub-bituminous. At temperature of $1000{ }^{\circ} \mathrm{C}(1273 \mathrm{~K})$, the addition of lignite of more than $2 \mathrm{wt} \%$ was capable of producing (Fe-Ni) alloys with high nickel recovery. Maximum amount of nickel was reporting to the alloy with the addition of lignite higher than $6 \mathrm{wt} \%$. (Fe, Ni)S was predicted to form first at $2 \mathrm{wt} \%$ lignite addition before any (Fe-Ni) alloy. The very first $(\mathrm{Fe}, \mathrm{Ni}) \mathrm{S}$ was predicted to be rich in nickel $(\sim 72 \% \mathrm{Ni})$ and gradually more iron reported to the sulfide. The sulfide formation gradually increased with increasing of lignite addition.

\subsection{Effect of $S$ and FeS Additions on Phases Formation at $1000{ }^{\circ} \mathrm{C}(1273 \mathrm{~K})$}

Figure 6 shows the thermodynamic predictions for carbothermic reduction of the laterite at $1000{ }^{\circ} \mathrm{C}$ $(1273 \mathrm{~K})$ with $4 \mathrm{wt} \% \mathrm{C}$ at different sulfur addition (1-5 wt \%). The presence of $\mathrm{S}$ appeared to stabilized the enstatite and destabilized both the $(\mathrm{Fe}, \mathrm{Ni})$ alloy and the forsterite. The presence of $\mathrm{S}$ induced the formation of sulfide, (Fe, Ni)S in liquid form. It can be seen from Figure $6 a$ that as the amount of $S$ was increased which means more sulfide $(\mathrm{Fe}, \mathrm{Ni}) \mathrm{S}$ was formed. This was at the expense of $(\mathrm{Fe}, \mathrm{Ni})$ alloy and forsterite. Figure $6 \mathrm{~b}$ shows the reduction of nickel (and total alloy) recovery down to 0 at $3 \mathrm{wt} \% \mathrm{~S}$ addition. The detailed of the fraction of nickel and iron presence as metal alloy and sulfide are presented in Figure $6 c, d$. Beyond $3 \mathrm{wt} \% \mathrm{~S}$ addition, further formation of the $(\mathrm{Fe}, \mathrm{Ni}) \mathrm{S}$ was at the expense of reduction of forsterite. Comparing with the carbothermic reduction without $S$ (only with $4 \mathrm{wt} \% \mathrm{C}$ ), the addition of $\mathrm{S}$ was predicted to reduce the amount of the metal alloys formed (due to the formation of the sulfide), which also means reducing the total nickel recovery. Nevertheless, the alloy formed was predicted to have a much better nickel grade. For every $1 \mathrm{wt} \% \mathrm{~S}$ increase in the addition, the nickel grade was increased by approximately $4 \%$. This appeared to be resulted from the more abundant of $\mathrm{Fe}$ that ejected from the $(\mathrm{Fe}, \mathrm{Ni})$ alloy to form the sulfide as sulphur was added.

Comparing the results presented in the current study with that of Elliott et al. $(2015 ; 2017)$, one can see the different effect of $S$ on the saprolitic and limonitic nickel laterite $[13,14]$. The thermodynamic modeling of the carbothermic reduction of limonite using $4 \mathrm{wt} \%$ coal and $1 \mathrm{wt} \% \mathrm{~S}$ at $1000{ }^{\circ} \mathrm{C}(1273$ K) carried out by Elliott et al. resulted in the value of nickel recovery and nickel grade of $97.8 \%$ and $14 \%$, respectively [13]. In the current study, the nickel recovery and nickel grade for the saprolite carbothermic reduction with addition of $4 \mathrm{wt} \% \mathrm{C}$ and $1 \mathrm{wt} \% \mathrm{~S}$ at $1000{ }^{\circ} \mathrm{C}(1273 \mathrm{~K})$ were predicted to be $73.4 \%$ and $34.5 \%$, respectively. Elliott et al. (2017) also reported that for limonite, the nickel recovery and the nickel grade were predicted to increase and decrease, respectively, with increasing of sulfur [14]. On the contrary for saprolite, the current study reported that the nickel recovery and the nickel grade were predicted to decrease and increase, respectively, with increasing of sulfur. This also highlighted that the nickel is associated with magnetite in the limonite and with forsterite in saprolite, and that their optimum reduction conditions are different. 

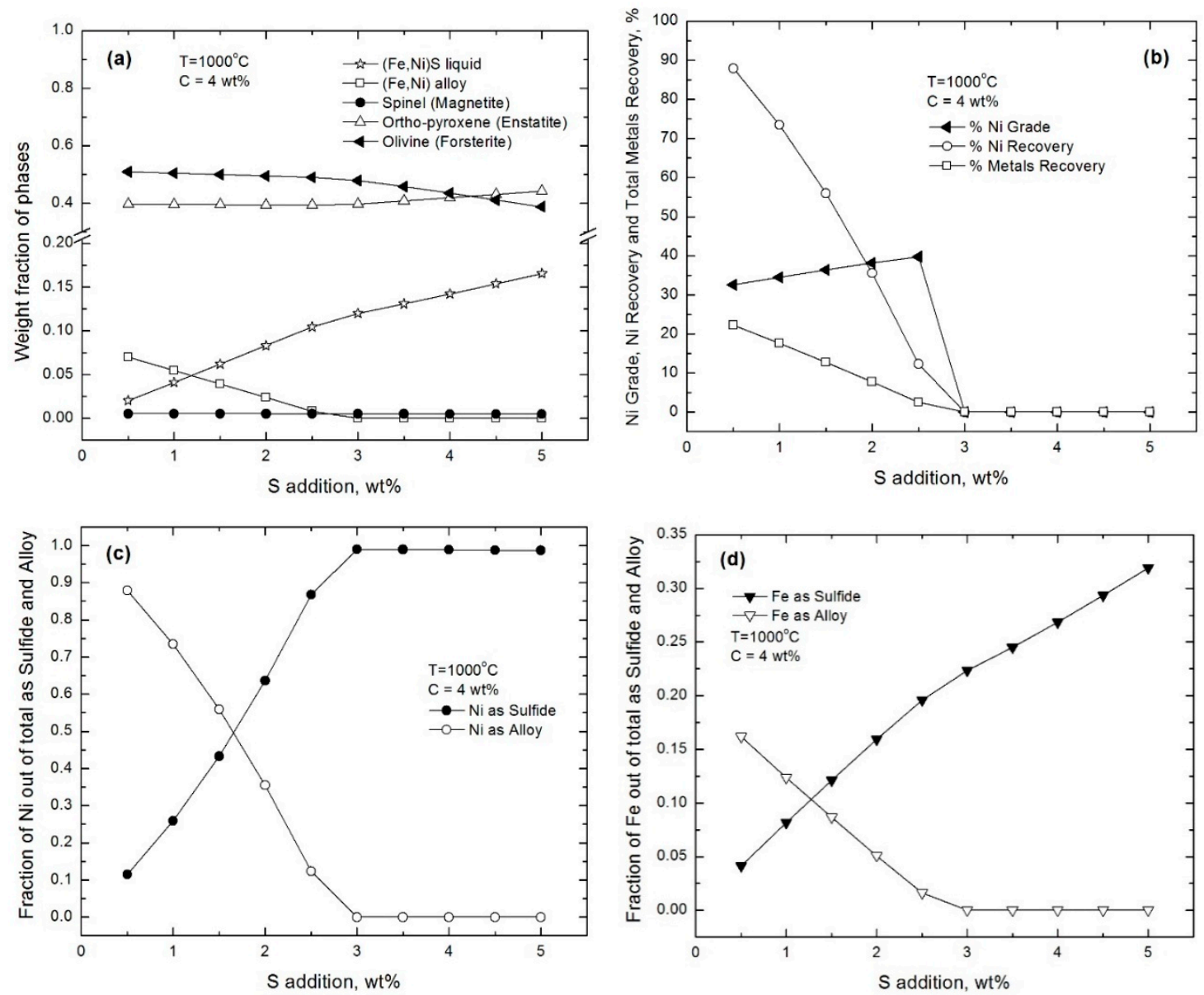

Figure 6. Thermodynamic predictions on (a) the condensed phases stability and formation (presented in weight fraction), (b) Ni grade, Ni recovery, and total metal recovery, (c) Ni fraction out of Ni total in sulfide and alloy, and (d) Fe fraction out of Fe total in sulfide and alloy, during carbothermic reduction using $4 \mathrm{wt} \% \mathrm{C}$ and with $\mathrm{S}$ at various concentration ( $1 \mathrm{wt} \%$ to $5 \mathrm{wt} \%)$ at $1000{ }^{\circ} \mathrm{C}(1273 \mathrm{~K})$. Legend: spinel (magnetite- $\left.(\mathrm{Fe}, \mathrm{Ni}, \mathrm{Mg}) \mathrm{O} .(\mathrm{Fe}, \mathrm{Cr}, \mathrm{Al})_{2} \mathrm{O}_{3}\right)$; ortho/proto-pyroxene (enstatite- $\left.(\mathrm{Mg}, \mathrm{Fe}) \mathrm{SiO}_{3}\right)$; olivine (forsterite- $\left.(\mathrm{Mg}, \mathrm{Fe}, \mathrm{Ni}, \mathrm{Mn}, \mathrm{Co})_{2} \mathrm{SiO}_{4}\right)$.

The effect of FeS addition on the carbothermic reduction of laterite using $4 \mathrm{wt} \% \mathrm{C}$ is shown in Figure 7. Figure 7a shows that enstatite, forsterite and magnetite were found to be relatively stable within the range of 1-5 wt \% FeS addition. With the increase of the FeS addition, there was steady increase of the formation of $(\mathrm{Fe}, \mathrm{Ni})$ sulfide and at the same time decrease in the $(\mathrm{Fe}, \mathrm{Ni})$ alloy. The nickel grade, the nickel and the total metals recoveries, were found to decrease with increasing of $\mathrm{FeS}$ addition, as shown in Figure $\mathrm{7b}$. The fraction of the $\mathrm{Ni}$ and $\mathrm{Fe}$ as alloy and as sulfide are shown in the Figure $7 \mathrm{c}, \mathrm{d}$. It can be clearly seen that as the FeS addition was increased, more nickel and iron report to the sulfide, with the expense of the (Fe, Ni) alloy. It was predicted that formation of the (Fe, $\mathrm{Ni}$ ) alloy, in the case of FeS addition, was larger compared to the case of $\mathrm{S}$ addition. The larger amount was due to the presence of more Fe in the system from the FeS addition that contribute to the formation of the $(\mathrm{Fe}, \mathrm{Ni})$ alloy. This, however, resulted in the much lower nickel grade (due to the presence of more Fe in the alloy) in the case of the FeS addition. The nickel grade was predicted to decrease by the amount of $0.8 \%$ for every $1 \mathrm{wt} \%$ increase of FeS addition. 

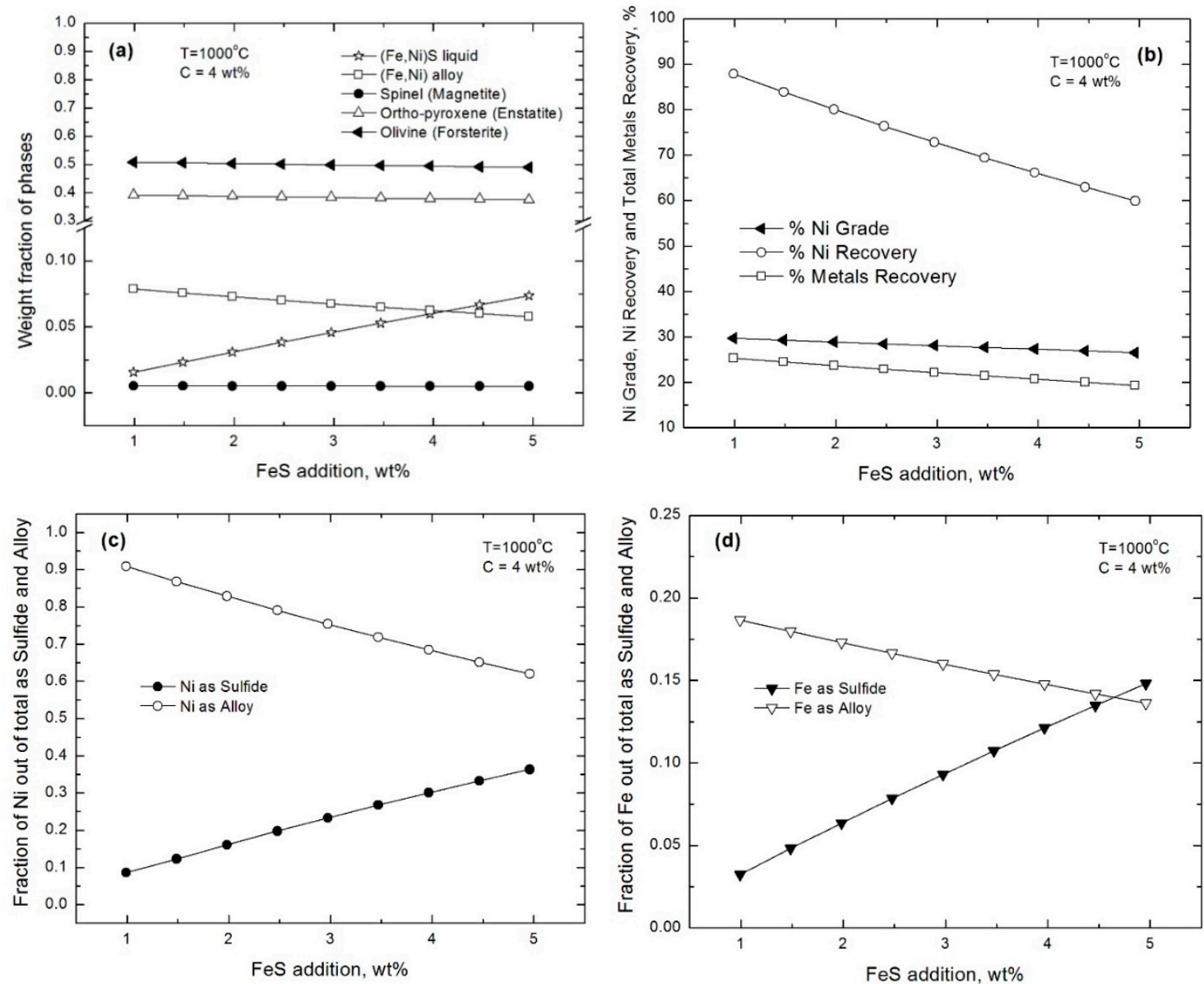

Figure 7. Thermodynamic predictions on (a) the condensed phases stability and formation (presented in weight fraction), (b) Ni grade, Ni recovery, and total metal recovery, (c) Ni fraction out of Ni total in sulfide and alloy, and (d) Fe fraction out of Fe total in sulfide and alloy, during carbothermic reduction using $4 \mathrm{wt} \% \mathrm{C}$ and with $\mathrm{FeS}$ at various concentration $(1 \mathrm{wt} \%$ to $5 \mathrm{wt} \%)$ at $1000{ }^{\circ} \mathrm{C}(1273 \mathrm{~K})$. Legend: spinel (magnetite- $\left.(\mathrm{Fe}, \mathrm{Ni}, \mathrm{Mg}) \mathrm{O} .(\mathrm{Fe}, \mathrm{Cr}, \mathrm{Al})_{2} \mathrm{O}_{3}\right)$; ortho/proto-pyroxene (enstatite- $\left.(\mathrm{Mg}, \mathrm{Fe}) \mathrm{SiO}_{3}\right)$; olivine (forsterite- $\left.(\mathrm{Mg}, \mathrm{Fe}, \mathrm{Ni}, \mathrm{Mn}, \mathrm{Co})_{2} \mathrm{SiO}_{4}\right)$.

\subsection{Effect of $\mathrm{Na}_{2} \mathrm{~S}$ and $\mathrm{Na}_{2} \mathrm{SO}_{4}$ Additions on Phases Formation at $1000{ }^{\circ} \mathrm{C}(1273 \mathrm{~K})$}

Figure 8 shows the thermodynamic predictions of the phase formation for the addition of $\mathrm{Na}_{2} \mathrm{~S}$ to the carbothermic reduction using $4 \mathrm{wt} \% \mathrm{C}$ at $100{ }^{\circ} \mathrm{C}(1273 \mathrm{~K})$. The phases formation was found to be quite different compared to the $\mathrm{S}$ and $\mathrm{FeS}$ additions. The presence of $\mathrm{Na}_{2} \mathrm{~S}$ promote the formation of two major phases-i.e., liquid silicate slag (rich in $\mathrm{Si}, \mathrm{Na}, \mathrm{Fe}, \mathrm{Al}, \mathrm{Mg}$ ) and Na-rich sulfide-as shown in Figure $8 \mathrm{a}$. As the $\mathrm{Na}_{2} \mathrm{~S}$ was added (1-2 wt \%) enstatite was reduced down and feldspar $\left(\mathrm{NaAlSi}_{3} \mathrm{O}_{8}\right)$ was formed. Further increase in the $\mathrm{Na}_{2} \mathrm{~S}(>2 \mathrm{wt} \%)$ promoted the formation of the liquid silicate slag. For example, at $4 \mathrm{wt} \% \mathrm{Na}_{2} \mathrm{~S}$ addition, about $21 \%$ of the condensed phases was the liquid slag with major composition of $58 \mathrm{wt} \% \mathrm{SiO}_{2}, 21.4 \mathrm{wt} \% \mathrm{NaAlO}_{2}, 7.6 \mathrm{wt} \% \mathrm{Na}_{2} \mathrm{O}, 8.08 \mathrm{wt} \% \mathrm{FeO}, 3.92 \mathrm{wt} \% \mathrm{MgO}$, and other sulfides and oxides. As the $\mathrm{Na}_{2} \mathrm{~S}$ was increased, more liquid slag phase was formed. 

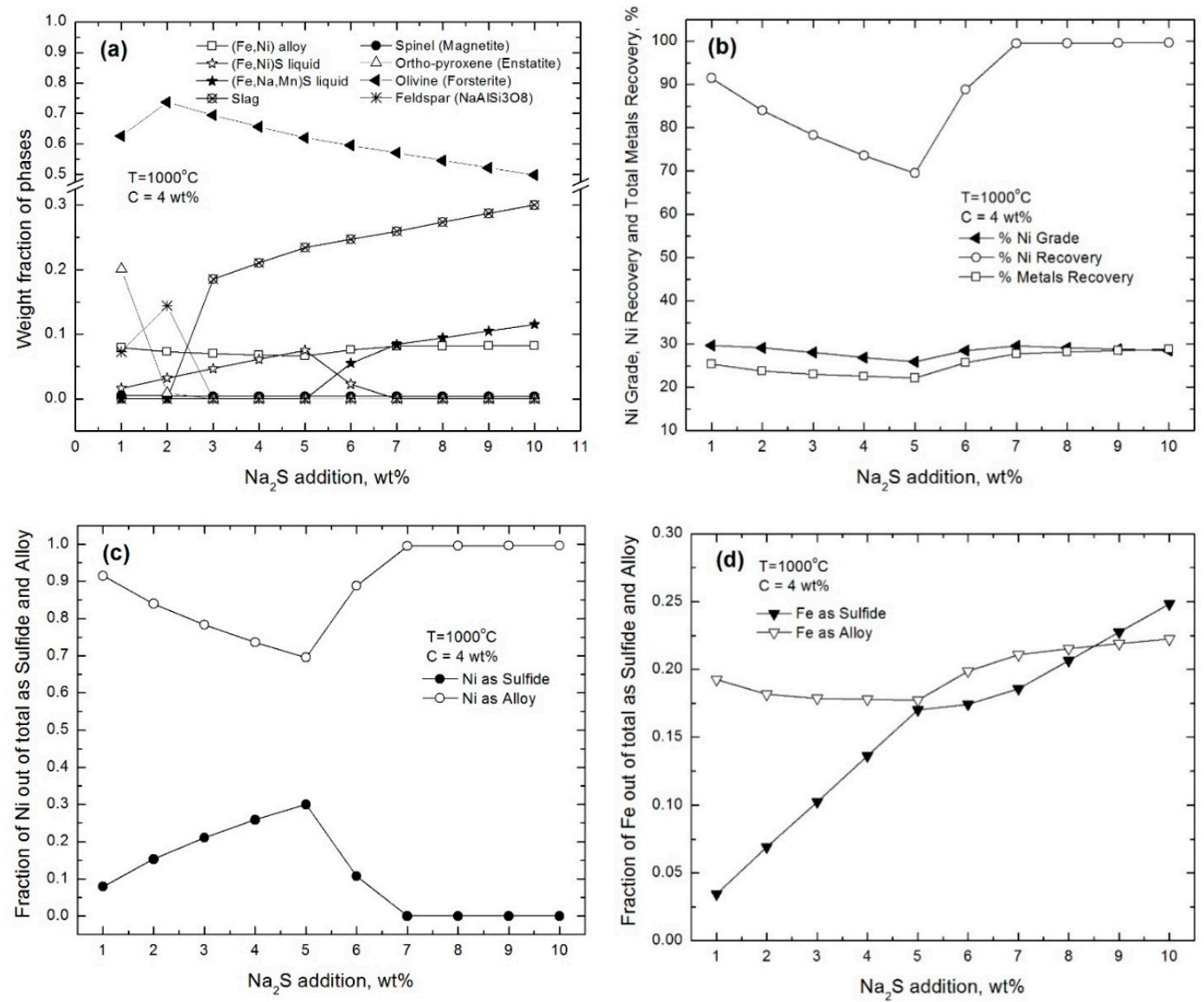

Figure 8. Thermodynamic predictions on (a) the condensed phases stability and formation (presented in weight fraction), (b) Ni grade, Ni recovery, and total metal recovery, (c) Ni fraction out of Ni total in sulfide and alloy, and (d) Fe fraction out of Fe total in sulfide and alloy, during carbothermic reduction using 4 wt \% C and with $\mathrm{Na}_{2} \mathrm{~S}$ at various concentration $(1-10 \mathrm{wt} \%)$ at $1000{ }^{\circ} \mathrm{C}(1273 \mathrm{~K})$. Legend: spinel (magnetite- $\left.(\mathrm{Fe}, \mathrm{Ni}, \mathrm{Mg}) \mathrm{O} .(\mathrm{Fe}, \mathrm{Cr}, \mathrm{Al})_{2} \mathrm{O}_{3}\right)$; ortho/proto-pyroxene (enstatite- $\left.(\mathrm{Mg}, \mathrm{Fe}) \mathrm{SiO}_{3}\right)$; olivine (forsterite- $\left.(\mathrm{Mg}, \mathrm{Fe}, \mathrm{Ni}, \mathrm{Mn}, \mathrm{Co})_{2} \mathrm{SiO}_{4}\right)$; feldspar $\left(\mathrm{NaAlSi}_{3} \mathrm{O}_{8}\right)$; slag (rich in $\mathrm{Na}, \mathrm{Al}, \mathrm{Fe}, \mathrm{Si}$ ).

The $\mathrm{Na}_{2} \mathrm{~S}$ also was predicted to promote the formation of sulfide. As the $\mathrm{Na}_{2} \mathrm{~S}$ was added from 1 to $5 \mathrm{wt} \%$, an increasing amount of liquid sulfide ( $\mathrm{Fe}, \mathrm{Ni}) \mathrm{S}$ was formed. This sulfide was rich in $\mathrm{Fe}, \mathrm{Ni}$, and $\mathrm{Co}$ but not containing $\mathrm{Na}$. Beyond $5 \mathrm{wt} \%$ addition of $\mathrm{Na}_{2} \mathrm{~S}$, a different type of sulfide $(\mathrm{Fe}, \mathrm{Na}, \mathrm{Mn}) \mathrm{S}$, rich in $\mathrm{Fe}$ and $\mathrm{Na}$, was formed. This sulfide had composition approximately, $81 \mathrm{wt} \% \mathrm{FeS}, 11.8 \mathrm{wt} \%$ $\mathrm{Na}_{2} \mathrm{~S}$, and other smaller amounts of $\mathrm{MnS}, \mathrm{MgS}$, and $\mathrm{FeO}$.

There was a slight decrease of $(\mathrm{Fe}, \mathrm{Ni})$ alloy formation when $\mathrm{Na}_{2} \mathrm{~S}$ was added of $1-5 \mathrm{wt} \%$. This was accompanied by a significant decrease in the nickel recovery from $91.4 \%$ to $70 \%$, as can be seen in Figure $8 \mathrm{~b}$. This coincided with the formation of $(\mathrm{Fe}, \mathrm{Ni}) \mathrm{S}$. As more $\mathrm{Na}_{2} \mathrm{~S}$ was added beyond $5 \mathrm{wt} \%$, it appeared that the $\mathrm{Ni}$ and $\mathrm{Fe}$ ejected back from $(\mathrm{Fe}, \mathrm{Ni}) \mathrm{S}$ to the alloy as the second type of sulfide $(\mathrm{Fe}, \mathrm{Na}, \mathrm{Mn}) \mathrm{S}$ was forming. The nickel recovery in the alloy was then increasing steadily to $99.6 \%$ at about $7 \mathrm{wt} \% \mathrm{Na}_{2} \mathrm{~S}$ addition which can be clearly seen in Figure $8 \mathrm{c}$. The nickel grade was decreasing down from $29.7 \%$ to $26 \%$ during addition from $1 \mathrm{wt} \%$ to $5 \mathrm{wt} \% \mathrm{Na}_{2} \mathrm{~S}$, but then increasing again beyond this point to $28.5 \%$ with the addition of $10 \mathrm{wt} \%$ of $\mathrm{Na}_{2} \mathrm{~S}$. With the addition of $\mathrm{Na}_{2} \mathrm{~S}$ above $8 \mathrm{wt} \%$, the amount of the Fe reported to the sulfide overtook the amount reported to the alloy, thus improving the nickel grade, as can be seen in Figure $8 \mathrm{~d}$. It appeared that the addition of $\mathrm{Na}_{2} \mathrm{~S}$ affect the nickel grade in a similar way to the case of $\mathrm{FeS}$ addition, i.e., the nickel grade was predicted to decrease by the amount of $0.8-0.95 \%$ for every $1 \mathrm{wt} \%$ increase of $\mathrm{Na}_{2} \mathrm{~S}$ addition. 
The effect of $\mathrm{Na}_{2} \mathrm{SO}_{4}$ addition on the carbothermic reduction of laterite with $4 \mathrm{wt} \% \mathrm{C}$ at $1000{ }^{\circ} \mathrm{C}$ $(1273 \mathrm{~K})$ is shown in Figure 9. The general phases formation behavior during $\mathrm{Na}_{2} \mathrm{SO}_{4}$ addition was found to be quite similar compared to $\mathrm{Na}_{2} \mathrm{~S}$ addition, as shown in Figure 9a. For example, the $\mathrm{Na}_{2} \mathrm{SO}_{4}$ addition promoted the formation of liquid silicate slag (rich in $\mathrm{Si}, \mathrm{Na}, \mathrm{Fe}, \mathrm{Al}, \mathrm{Mg}$ ). The $\mathrm{Na}_{2} \mathrm{SO}_{4}$ also destabilized the enstatite. Rather, feldspar $\mathrm{NaAlSi}_{3} \mathrm{O}_{8}$ was formed at low addition of $\mathrm{Na}_{2} \mathrm{SO}_{4}(<3 \mathrm{wt} \%)$. At higher concentration ( $>3 \mathrm{wt} \%$ ), liquid silicate slag was formed as opposed to feldspar. Increasing amount of $\mathrm{Na}_{2} \mathrm{SO}_{4}$ resulted in more liquid silicate slag to form.
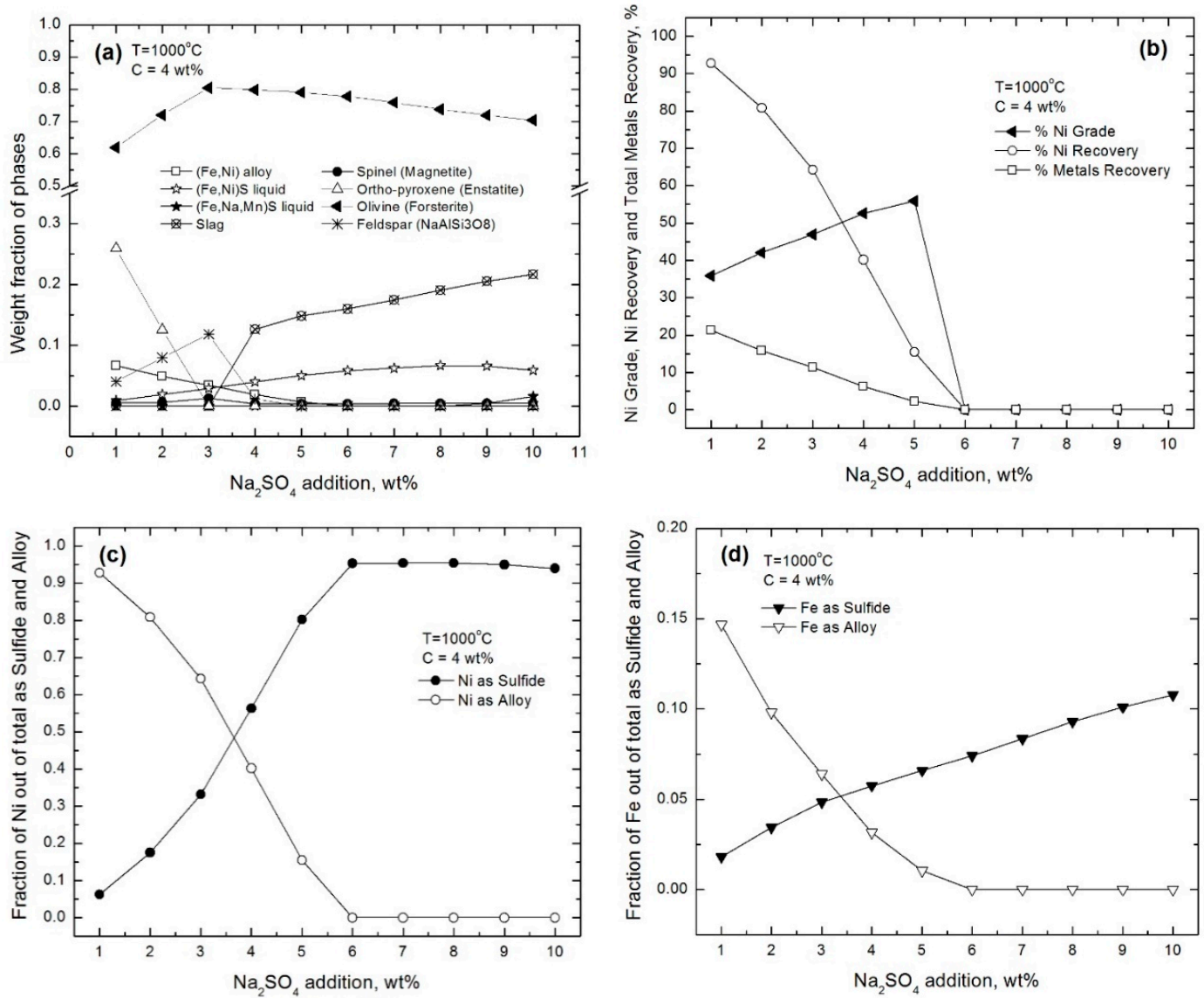

Figure 9. Thermodynamic predictions on (a) the condensed phases stability and formation (presented in weight fraction), (b) Ni grade, Ni recovery, and total metal recovery, (c) Ni fraction out of Ni total in sulfide and alloy, and (d) Fe fraction out of Fe total in sulfide and alloy, during carbothermic reduction using $4 \mathrm{wt} \% \mathrm{C}$ and with $\mathrm{Na}_{2} \mathrm{SO}_{4}$ at various concentration $(1 \mathrm{wt} \%$ to $10 \mathrm{wt} \%)$ at $1000^{\circ} \mathrm{C}(1273 \mathrm{~K})$. Legend: spinel (magnetite- $\left.(\mathrm{Fe}, \mathrm{Ni}, \mathrm{Mg}) \mathrm{O} .(\mathrm{Fe}, \mathrm{Cr}, \mathrm{Al})_{2} \mathrm{O}_{3}\right)$; ortho/proto-pyroxene (enstatite- $\left.(\mathrm{Mg}, \mathrm{Fe}) \mathrm{SiO}_{3}\right)$; olivine (forsterite- $\left.(\mathrm{Mg}, \mathrm{Fe}, \mathrm{Ni}, \mathrm{Mn}, \mathrm{Co})_{2} \mathrm{SiO}_{4}\right)$; feldspar $\left(\mathrm{NaAlSi}_{3} \mathrm{O}_{8}\right)$; slag (rich in $\mathrm{Na}, \mathrm{Al}, \mathrm{Fe}, \mathrm{Si}$ ).

The addition of $\mathrm{Na}_{2} \mathrm{SO}_{4}$ also destabilize the (Fe,Ni) alloy. The more the $\mathrm{Na}_{2} \mathrm{SO}_{4}$ was added, the more (Fe,Ni) alloy turned to sulfide. Two different types of sulfides were also observed, i.e., the $(\mathrm{Fe}, \mathrm{Ni}) \mathrm{S}$ and the $(\mathrm{Fe}, \mathrm{Na}, \mathrm{Mn}) \mathrm{S}$. One major difference between the $\mathrm{Na}_{2} \mathrm{SO}_{4}$ and $\mathrm{Na}_{2} \mathrm{~S}$ was the fact that the formation of the second type of sulfide $(\mathrm{Fe}, \mathrm{Na}, \mathrm{Mn}) \mathrm{S}$ occurred at much larger addition of $\mathrm{Na}_{2} \mathrm{SO}_{4}$ ( $>9 \mathrm{wt} \%$ ). By this point, all the $(\mathrm{Fe}, \mathrm{Ni})$ had already transformed to the type 1 sulfide $(\mathrm{Fe}, \mathrm{Ni}) \mathrm{S}$.

Figure $9 \mathrm{~b}$ shows the nickel grade, nickel recovery, and total metal recovery for the addition of $\mathrm{Na}_{2} \mathrm{SO}_{4}$. Unlike the case of $\mathrm{Na}_{2} \mathrm{~S}$ addition, $\mathrm{Na}_{2} \mathrm{SO}_{4}$ addition gave an increase in the nickel grade after the reduction. Increasing the amount of $\mathrm{Na}_{2} \mathrm{SO}_{4}$ from 1 wt \% to 5 wt \% resulted in the increase in the nickel grade from $36 \%$ to $56 \%$. This provided the same positive effect of nickel grade increase as carbothermic reduction with $\mathrm{S}$ addition. In fact, for the same amount of addition (in weight), $\mathrm{Na}_{2} \mathrm{SO}_{4}$ 
provided a higher nickel grade. For example, $2 \mathrm{wt} \% \mathrm{Na}_{2} \mathrm{SO}_{4}$ addition gave a nickel grade of $42.1 \%$, while 2 wt $\%$ of $S$ provided $38.2 \%$ nickel grade.

Figure $9 \mathrm{c}, \mathrm{d}$ show the fraction of $\mathrm{Ni}$ and $\mathrm{Fe}$ in the form of (Fe.Ni) alloy and sulfide. It can be clearly seen here that as the $\mathrm{Na}_{2} \mathrm{SO}_{4}$ addition was increased, more $\mathrm{Ni}$ and Fe were rejected from the $(\mathrm{Fe}, \mathrm{Ni})$ alloy to form the liquid $(\mathrm{Fe}, \mathrm{Ni}) \mathrm{S}$. All the metal was transformed to the $(\mathrm{Fe}, \mathrm{Ni}) \mathrm{S}$ at $6 \mathrm{wt} \%$ $\mathrm{Na}_{2} \mathrm{SO}_{4}$ addition.

Jiang et al. (2013) carried out an experimental study on carbothermic reduction of saprolite using $2 \mathrm{wt} \%$ coal at $1200^{\circ} \mathrm{C}(1473 \mathrm{~K})$ with different additives including $\mathrm{Na}_{2} \mathrm{~S}$ and $\mathrm{Na}_{2} \mathrm{SO}_{4}$ [17]. In the case of the addition of $10 \mathrm{wt} \% \mathrm{Na}_{2} \mathrm{~S}$ and $\mathrm{Na}_{2} \mathrm{SO}_{4}$, they reported the presence of nepheline- $\mathrm{Na}_{3} \mathrm{MgAl}\left(\mathrm{SiO}_{4}\right)_{2}$ in the system from their XRD analyses of samples at room temperature. Most likely, this phase was crystallized from the liquid silicate slag at the reaction temperature. This is in general agreement with the prediction of the formation of feldspar and Na-rich liquid silicate slag at the reaction temperature as described in the current study. Their study also suggested that the general effect of the addition of $\mathrm{Na}_{2} \mathrm{~S}$ and $\mathrm{Na}_{2} \mathrm{SO}_{4}$ are increasing the nickel grade of the alloy. This is also in agreement with the current study, although our predictions were giving a much higher nickel grade. The nickel grades reported by Jiang et al. (2013) for $5 \mathrm{wt} \%$ additions of $\mathrm{Na}_{2} \mathrm{~S}$ and $\mathrm{Na}_{2} \mathrm{SO}_{4}$ (at $1200{ }^{\circ} \mathrm{C}$ and $2 \mathrm{wt} \%$ coal) after magnetic separation are $7.8 \%$ and $6.5 \%$, respectively [17]. While the predictions from the current study for $5 \mathrm{wt} \%$ additions of $\mathrm{Na}_{2} \mathrm{~S}$ and $\mathrm{Na}_{2} \mathrm{SO}_{4}$ (at $1000{ }^{\circ} \mathrm{C}(1273 \mathrm{~K})$ and $4 \% \mathrm{C}$ ) are $68 \%$ and $56 \%$, respectively.

Jiang et al. (2013) reported that the addition of $\mathrm{Na}_{2} \mathrm{~S}$ and $\mathrm{Na}_{2} \mathrm{SO}_{4}$ resulted in the increase of nickel recovery when the additives were added up to $5 \mathrm{wt} \%$; and beyond this with point with further increase in the additives' concentration, the nickel recovery was observed to decrease [17]. The current study, however, predicted the decrease of the nickel recovery, immediately after $\mathrm{Na}_{2} \mathrm{~S}$ and $\mathrm{Na}_{2} \mathrm{SO}_{4}$ were added. This discrepancy could be due the different amount of $C$ and temperature used in the study. They also measured the nickel grade after magnet separation process. The detailed process of the magnetic separation was not presented in their paper. Incomplete liberation of Ni-containing phase from bulk forsterite particle could provide distortion of the nickel grade measurement after magnet separation. In other studies, Rao et al. (2016a; 2016b) reported that, in the case of carbothermic reduction of saprolite ore using $\mathrm{CO}$ gas at $1050{ }^{\circ} \mathrm{C}$, the nickel metallization was increased with increasing $\mathrm{Na}_{2} \mathrm{SO}_{4}$, which also contradicts the predictions from the current study $[18,19]$. It should be noted that the system used for the experiment by Rao et al. was an open system, and CO gas was used instead of $C$ which affect the effective reduction potential at temperature. From their microstructure characterization result, it was also clear that there were complex microstructures forming such as encapsulation of ( $\mathrm{Fe}, \mathrm{Ni})$ alloy by FeS which can affect the kinetics, which could not be taken into account in thermodynamic calculations. All of these can contribute to the discrepancies observed.

\subsection{Effect of $\mathrm{CaSO}_{4}$ Addition on Phases Formation at $1000^{\circ} \mathrm{C}(1273 \mathrm{~K})$}

Figure 10 shows the phases formation in the case of carbothermic reduction using $4 \mathrm{wt} \% \mathrm{C}$ with different amount of $\mathrm{CaSO}_{4}(1-10 \mathrm{wt} \%)$ at $1000{ }^{\circ} \mathrm{C}(1273 \mathrm{~K})$. There are a number key differences on the phases formation during $\mathrm{CaSO}_{4}$ addition compared to $\mathrm{Na}_{2} \mathrm{SO}_{4}$ addition, as can be seen from Figure 10a. First, there was no formation of liquid silicate slag. The forsterite phase appeared to be stable over the range of $1-10 \mathrm{wt} \% \mathrm{CaSO}_{4}$ addition and was the major phase. The enstatite phase appeared to be quite stable as well in this range, although some reduction of enstatite was observed, i.e., its fraction decreased from 0.34 to 0.13 before it went up again to 0.19 at $10 \mathrm{wt} \% \mathrm{CaSO}_{4}$ addition. The $(\mathrm{Fe}, \mathrm{Ni})$ alloy gradually transformed to $(\mathrm{Fe}, \mathrm{Ni}) \mathrm{S}$ as more $\mathrm{CaSO}_{4}$ was added to the system. In this system, the formation of anorthite $\mathrm{CaAl}_{2} \mathrm{Si}_{2} \mathrm{O}_{8}$ was observed. As the $\mathrm{CaSO}_{4}$ was added from $1 \mathrm{wt} \%$ to $6 \mathrm{wt} \%$, the anorthite fraction was increased from 0.017 to 0.06 before it decreased down again to 0 at $10 \mathrm{wt} \%$ $\mathrm{CaSO}_{4}$ addition. 

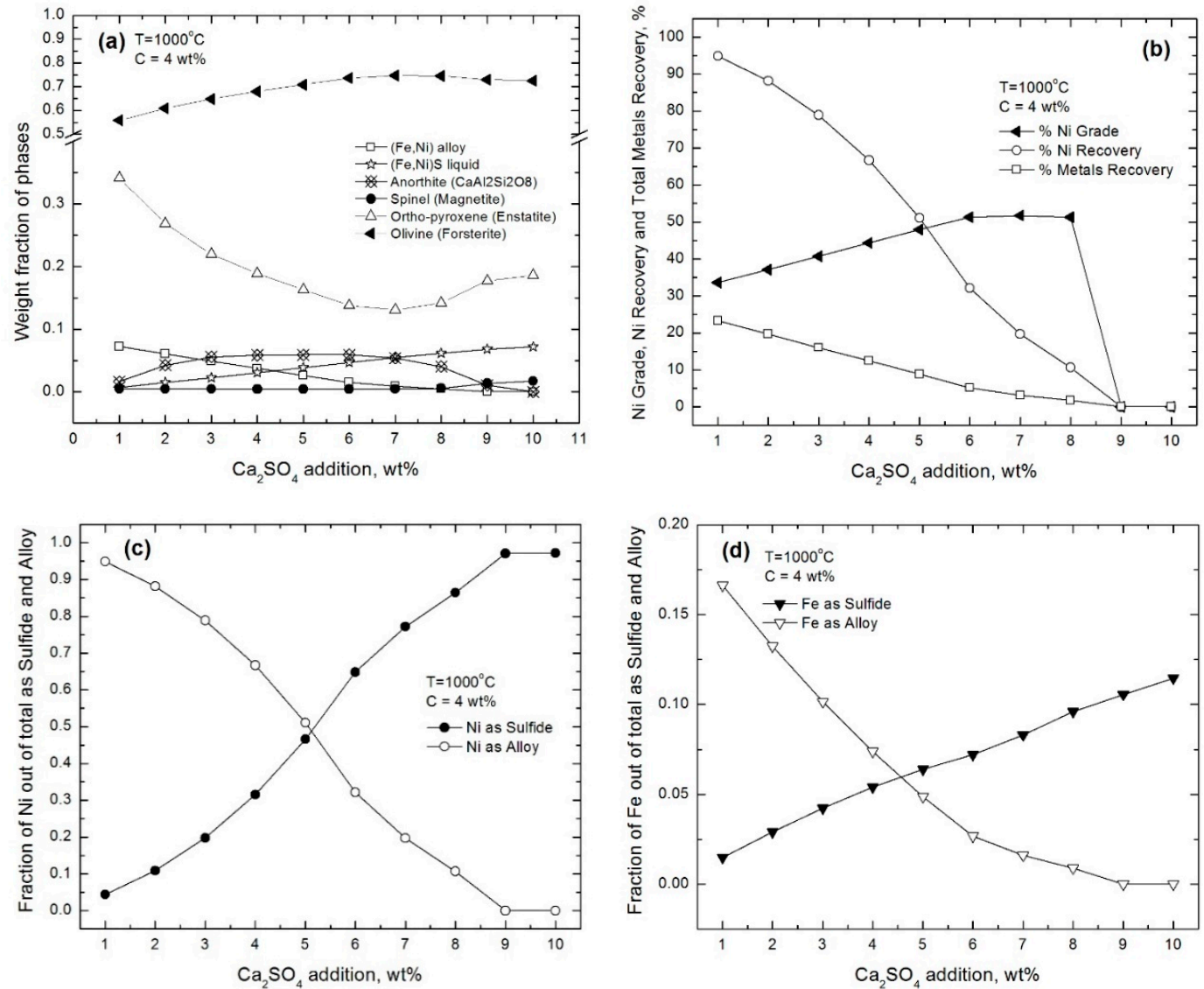

Figure 10. Thermodynamic predictions on (a) the condensed phases stability and formation (presented in weight fraction), (b) Ni grade, Ni recovery, and total metal recovery, (c) Ni fraction out of Ni total in sulfide and alloy, and (d) Fe fraction out of Fe total in sulfide and alloy, during carbothermic reduction using $4 \mathrm{wt} \% \mathrm{C}$ and with $\mathrm{CaSO}_{4}$ at various concentration ( $1 \mathrm{wt} \%$ to $\left.10 \mathrm{wt} \%\right)$ at $1000{ }^{\circ} \mathrm{C}(1273 \mathrm{~K})$. Legend: spinel (magnetite- $\left.(\mathrm{Fe}, \mathrm{Ni}, \mathrm{Mg}) \mathrm{O} .(\mathrm{Fe}, \mathrm{Cr}, \mathrm{Al})_{2} \mathrm{O}_{3}\right)$; ortho/proto-pyroxene (enstatite- $\left.(\mathrm{Mg}, \mathrm{Fe}) \mathrm{SiO}_{3}\right)$; olivine (forsterite- $\left.(\mathrm{Mg}, \mathrm{Fe}, \mathrm{Ni}, \mathrm{Mn}, \mathrm{Co})_{2} \mathrm{SiO}_{4}\right)$; anorthite $\left(\mathrm{CaAl}_{2} \mathrm{Si}_{2} \mathrm{O}_{8}\right)$.

The effect of $\mathrm{CaSO}_{4}$ addition on the nickel grade can be seen in Figure 10b. The effect of $\mathrm{CaSO}_{4}$ was positive in increasing the nickel grade. As more $\mathrm{CaSO}_{4}$ was added from $1 \mathrm{wt} \%$ to $7 \mathrm{wt} \%$, the nickel grade increased from $33.6 \%$ to $51.7 \%$, respectively. The increasing effect of the nickel grade appeared to be similar to the effect of $\mathrm{S}$ addition, but still lower compared to the $\mathrm{Na}_{2} \mathrm{SO}_{4}$ addition.

The fraction of nickel in the $(\mathrm{Fe}, \mathrm{Ni})$ alloy decreased from 0.94 to 0 when the $\mathrm{CaSO}_{4}$ addition was increased from $1 \mathrm{wt} \%$ to $9 \mathrm{wt} \%$, as can be seen in Figure 10c. Similarly the fraction of $\mathrm{Fe}$ in the $(\mathrm{Fe}, \mathrm{Ni})$ alloy also decreased from 0.17 to 0 over the same range of $\mathrm{CaSO}_{4}$ addition (Figure 10d).

\subsection{Comparison of the Effect of Additives on Phases Formation at $1000^{\circ} \mathrm{C}(1273 \mathrm{~K})$}

Figure 11 was constructed for easy comparison of the effect of different additives on the carbothermic reduction of laterite using $4 \mathrm{wt} \% \mathrm{C}$ at $1000{ }^{\circ} \mathrm{C}(1273 \mathrm{~K})$. Figure 11 a shows the comparison of the amount of $(\mathrm{Fe}, \mathrm{Ni})$ alloy was formed with increasing amount of different additives. The nickel grade and nickel recovery are shown in Figure $11 \mathrm{~b}, \mathrm{c}$, respectively. Figure $11 \mathrm{~d}$ shows the amount of sulfide that was formed. In this graph, the different type of sulfides were combined (e.g., in the case of $\mathrm{Na}_{2} \mathrm{SO}_{4}$ addition). There are a number of key points that can be drawn from these results:

- Generally, the selected additives would react with laterite and in particular with ( $\mathrm{Fe}, \mathrm{Ni}$ ) alloy to form sulfides, therefore reducing the amount of $(\mathrm{Fe}, \mathrm{Ni})$ alloy formed at equilibrium. On the basis 
of the same amount of addition (in weight), the effect of additives on the amount of (Fe, $\mathrm{Ni}$ ) alloy that was formed, from high to low, is ranked as follows: $\mathrm{Na}_{2} \mathrm{~S}>\mathrm{FeS}>\mathrm{CaSO}_{4}>\mathrm{Na}_{2} \mathrm{SO}_{4}>\mathrm{S}$

- The addition of these additives promote the formation of the (Fe,Ni)S. Since this sulfide forms with the expense of FeNi alloys, one may speculate that the sulfide liquid would form in the vicinity of FeNi alloys. On the basis of the same amount of addition (in weight), the degree of sulfide formation from high to low, is ranked as follows: $\mathrm{S}>\mathrm{FeS}=\mathrm{Na}_{2} \mathrm{~S}>\mathrm{Na}_{2} \mathrm{SO}_{4}>\mathrm{CaSO}_{4}$

- $\mathrm{FeS}$ and $\mathrm{Na}_{2} \mathrm{~S}$ additions were found to reduce the Ni grade; while $\mathrm{S}, \mathrm{Na}_{2} \mathrm{SO}_{4}$, and $\mathrm{CaSO}_{4}$ increase the Ni grade.

- At low addition of additives $(<2 \mathrm{wt} \%)$, the effect of additives on the nickel recovery (from high to low) is ranked as; $\mathrm{CaSO}_{4}>\mathrm{Na}_{2} \mathrm{~S}=\mathrm{FeS}=\mathrm{Na}_{2} \mathrm{SO}_{4}>\mathrm{S}$. While at large addition of additives $\left(>4 \mathrm{wt} \%\right.$ ) the rank is: $\mathrm{Na}_{2} \mathrm{~S}>\mathrm{FeS}>\mathrm{CaSO}_{4}>\mathrm{Na}_{2} \mathrm{SO}_{4}>\mathrm{S}$.
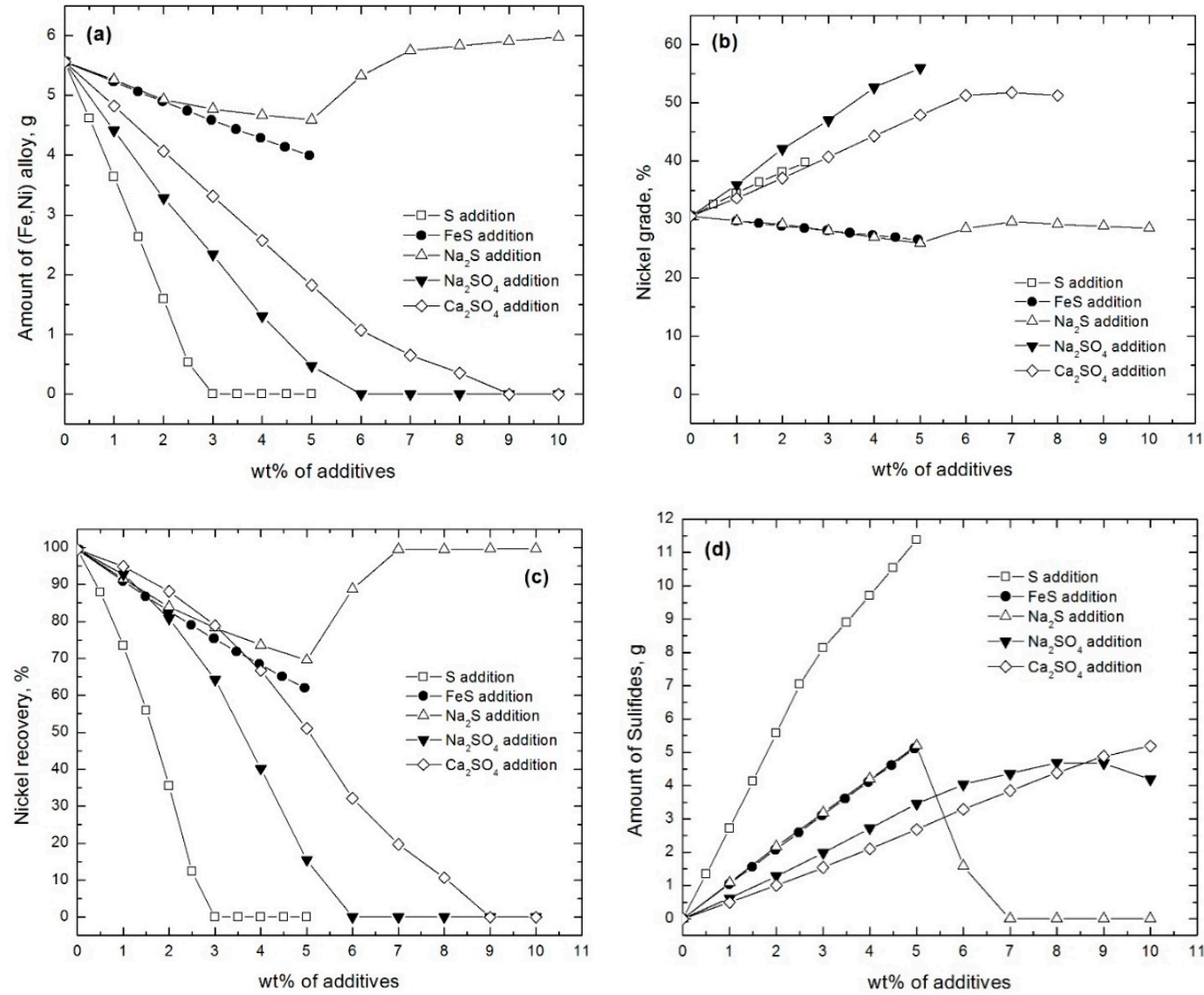

Figure 11. Thermodynamic predictions on the comparison of the addition of different additives on (a) the amount of (Fe,Ni) alloy, (b) the nickel grade in \%, (c) the nickel recovery in\%, and (d) the amount of sulfide phase, for carbothermic reduction using 4 wt $\% \mathrm{C}$ at $1000{ }^{\circ} \mathrm{C}(1273 \mathrm{~K})$.

Therefore, it can be seen that the effect of additives is quite complex, and the addition of these additives will need some consideration of balancing the formation of liquid sulfides, liquid slag, formation of the $(\mathrm{Fe}, \mathrm{Ni})$ alloy and the nickel grade. It should be re-emphasized that the calculations presented only consider the thermodynamic/equilibrium where all elements and phases readily react to form a new equilibrium state, not including the kinetics effect. In actuality, the unavailability of phase reactants could result in local equilibrium that has complete different phases composition. The fact that there is formation of liquid phases such as liquid sulfides and liquid slag might assist in the mass transfer of species or, on the contrary, provide a barrier for further reactions through encapsulation of phases (e.g., (Fe, Ni) alloy), were not reflected in the present calculations. 
Thus, some experimental studies coupled with detailed material characterizations will need to be carried out for validation of the simulation and to comprehensively analyze the effect of these additives. This will be the subject of further study from the authors.

\section{Conclusions}

Systematic and comprehensive thermodynamic analyses of the carbothermic reduction of saprolitic laterite-including the effect of additives $\mathrm{S}, \mathrm{FeS}, \mathrm{Na}_{2} \mathrm{~S}, \mathrm{Na}_{2} \mathrm{SO}_{4}$, and $\mathrm{CaSO}_{4}$ - have been carried out in the present study. There are a number of points that can be drawn from the study:

(1) From a thermodynamic perspective, the use of lower rank coal such as sub-bituminous and lignite as a source of carbon as reductant for the carbothermic reduction of saprolitic nickel laterite did not provide a significant effect on the nickel grade and nickel recovery; rather, the total metal recovery is affected. This is mainly due to the lower availability of carbon for reduction reaction.

(2) The main difference in the phase's formation when sub-bituminous and lignite are used as reductant is the formation of sulfide phases due to the presence of $S$ in these $C$-sources.

(3) At $1000{ }^{\circ} \mathrm{C}(1273 \mathrm{~K})$, only small amounts of C-sources (C, sub-bituminous, lignite) are needed to significantly metallize the nickel in the laterite, i.e., between $4-6 \mathrm{wt} \%$.

(4) At $4 \mathrm{wt} \% \mathrm{C}$ and at $1000{ }^{\circ} \mathrm{C}(1273 \mathrm{~K})$, the additions of $\mathrm{S}, \mathrm{FeS}, \mathrm{Na}_{2} \mathrm{~S}, \mathrm{Na}_{2} \mathrm{SO}_{4}$, and $\mathrm{CaSO}_{4}$ promote the formation of liquid sulfides, and at the same time reduce the formation of the $(\mathrm{Fe}, \mathrm{Ni}$ ) alloy (thus reducing the nickel and total metals recovery). Therefore, consideration is needed to balance the two aspects.

(5) The different phase formations (due to the additives) affect the amount of the $\mathrm{Ni}$ and Fe that is ejected from the $(\mathrm{Fe}, \mathrm{Ni})$ alloy and thus have a direct effect on the nickel grade and nickel recovery. The calculations predicted that $\mathrm{S}, \mathrm{Na}_{2} \mathrm{SO}_{4}$, and $\mathrm{CaSO}_{4}$ additions provided an increase in the nickel grade; while $\mathrm{FeS}$ and $\mathrm{Na}_{2} \mathrm{~S}$ reduced the nickel grade.

(6) In the case of additions of $\mathrm{N}_{2} \mathrm{~S}$ and $\mathrm{Na}_{2} \mathrm{SO}_{4}$, the presence of Na predicted to destabilize enstatite and promote the formation of feldspar $\left(\mathrm{NaAlSi}_{3} \mathrm{O}_{8}\right)$ at low addition; and formation of liquid silicate slag (rich in $\mathrm{Na}$ ) at high addition of the additives. In these two systems, two types of liquid sulfides were also observed to form. One is the $(\mathrm{Fe}, \mathrm{Ni}) \mathrm{S}$ and the other one is $(\mathrm{Fe}, \mathrm{Na}, \mathrm{Mn}) \mathrm{S}$. It appeared that the presence of a high amount of Na promote the formation of the second type of sulfide.

(7) Formation of anorthite $\left(\mathrm{CaAl}_{2} \mathrm{Si}_{2} \mathrm{O}_{8}\right)$ was predicted in the case of addition of $\mathrm{CaSO}_{4}$, However, at a large addition of $\mathrm{CaSO}_{4}(10 \mathrm{wt} \%)$ the anorthite was suppressed.

It should be noted that no kinetic aspects were considered in the discussion presented in the current paper (only the thermodynamics/equilibrium aspects). The calculations were also carried out considering closed systems. Clearly, experimental study to validate the thermodynamic assessments is needed, which will be the subject of further work by the authors.

Author Contributions: S.H. conceptualized the idea and discussed with M.A.R.; M.A.R. conducted simulations; M.A.R. and S.H. analyzed the data; S.H. and M.A.R. wrote and revised the manuscript.

Acknowledgments: The authors would like to thank the Ministry of Research, Technology and Higher Education, Republic Indonesia for the funding of the current research project, under the World Class Professor 2018 Program, Scheme B (no. 123.3.6/D2.3/KP/2018).

Conflicts of Interest: The authors declare no conflict of interest.

\section{References}

1. McRae, M. Nickel: Minerals Commodity Summary; U.S. Geological Survey: Reston, VA, USA, 2018; p. 112.

2. Mudd, G.M. Global trends and environmental issues in nickel mining: Sulfides versus laterites. Ore Geol. Rev. 2010, 38, 9-26. [CrossRef]

3. Chen, T.T.; Dutrizac, J.E.; Krause, E.; Osborne, R. Mineralogical Characterization of Nickel Laterites from New Caledonia and Indonesia. In International Laterite Nickel Symposium 2004, 2004 TMS Annual Meeting, Proceedings, Charlotte, US, Mar 14-18, 2004; The Minerals, Metals and Materials Society (TMS): Warrendale, PA, USA, 2004; pp. 79-99. 
4. Rhamdhani, M.A.; Hayes, P.C.; Jak, E. Nickel laterite Part 1 - microstructure and phase characterisations during reduction roasting and leaching. Miner. Process. Extr. Met. 2009, 118, 129-145. [CrossRef]

5. Zhu, D.; Cui, Y.; Vining, K.; Hapugoda, S.; Douglas, J.; Pan, J.; Zheng, G. Upgrading low nickel content laterite ores using selective reduction followed by magnetic separation. Int. J. Miner. Process. 2012, 106, 1-7. [CrossRef]

6. Mills, S.J. Global perspective on the use of low-quality coals. IEA Clean Coal Cent. 2011, 180, 1-2.

7. Anonymous. BP Statistical Review of World Energy. 2014. Available online: http://large.stanford.edu/ courses/2014/ph240/milic1/docs/bpreview.pdf. (accessed on 15 October 2019).

8. Lv, X.W.; Bai, C.G.; He, S.P.; Huang, Q.Y. Mineral Change of Philippine and Indonesia Nickel Lateritic Ore during Sintering and Mineralogy of Their Sinter. ISIJ Int. 2010, 50, 380-385. [CrossRef]

9. Kim, J.; Dodbiba, G.; Tanno, H.; Okaya, K.; Matsuo, S.; Fujita, T. Calcination of low-grade laterite for concentration of Ni by magnetic separation. Miner. Eng. 2010, 23, 282-288. [CrossRef]

10. Rao, M.; Li, G.; Jiang, T.; Luo, J.; Zhang, Y.; Fan, X. Carbothermic Reduction of Nickeliferous Laterite Ores for Nickel Pig Iron Production in China: A Review. JOM 2013, 65, 1573-1583. [CrossRef]

11. Rhamdhani, M.A.; Hayes, P.C.; Jak, E. Nickel laterite Part 2-thermodynamic analysis of phase transformations occurring during reduction roasting. Miner. Process. Extr. Met. 2009, 118, 146-155. [CrossRef]

12. Pickles, C.; Forster, J.; Elliott, R. Thermodynamic analysis of the carbothermic reduction roasting of a nickeliferous limonitic laterite ore. Miner. Eng. 2014, 65, 33-40. [CrossRef]

13. Elliott, R.; Rodrigues, F.; Pickles, C.A.; Peacey, J. A two-stage thermal upgrading process for nickeliferous limonitic laterite ores. Can. Met. Q. 2015, 54, 395-405. [CrossRef]

14. Elliott, R.; Pickles, C.; Peacey, J. Ferronickel particle formation during the carbothermic reduction of a limonitic laterite ore. Miner. Eng. 2017, 100, 166-176. [CrossRef]

15. Forster, J.; Pickles, C.; Elliott, R. Microwave carbothermic reduction roasting of a low grade nickeliferous silicate laterite ore. Miner. Eng. 2016, 88, 18-27. [CrossRef]

16. Chen, G.-J.; Hwang, W.-S.; Liu, S.-H.; Shiau, J.-S. The Effect of Bio-Coal on the Carbothermic Reduction of Laterite Ores. Mater. Trans. 2015, 56, 550-555. [CrossRef]

17. Jiang, M.; Sun, T.; Liu, Z.; Kou, J.; Liu, N.; Zhang, S. Mechanism of sodium sulfate in promoting selective reduction of nickel laterite ore during reduction roasting process. Int. J. Miner. Process. 2013, 123, 32-38. [CrossRef]

18. Rao, M.; Li, G.; Zhang, X.; Luo, J.; Peng, Z.; Jiang, T. Reductive roasting of nickel laterite ore with sodium sulfate for Fe-Ni production. Part 1. Reduction/sulfidation characteristics. Sep. Sci. Technol. 2016, 51, 1408-1420. [CrossRef]

19. Rao, M.; Li, G.; Zhang, X.; Luo, J.; Peng, Z.; Jiang, T. Reductive roasting of nickel laterite ore with sodium sulfate for Fe-Ni production. Part 2. Phase transformation and grain growth. Sep. Sci. Technol. 2016, 51, 1727-1735. [CrossRef]

20. Valix, M.; Cheung, W.; Cheung, A. Effect of sulfur on the mineral phases of laterite ores at high temperature reduction. Miner. Eng. 2002, 15, 523-530. [CrossRef]

21. Li, G.; Shi, T.; Rao, M.; Jiang, T.; Zhang, Y. Beneficiation of nickeliferous laterite by reduction roasting in the presence of sodium sulfate. Miner. Eng. 2012, 32, 19-26. [CrossRef]

22. Bale, C.W.; Belisle, E.; Chartrand, P.; Decterov, S.A.; Eriksson, G.; Hack, K.; Jung, I.-H.; Kang, Y.-B.; Melancon, J.; Pelton, A.D.; et al. FactSage thermochemical software and databases. Calphad 2002, 26, 189-228. [CrossRef]

(C) 2019 by the authors. Licensee MDPI, Basel, Switzerland. This article is an open access article distributed under the terms and conditions of the Creative Commons Attribution (CC BY) license (http://creativecommons.org/licenses/by/4.0/). 